\title{
An Early Stone Age in Western Africa? Spheroids and polyhedrons at Ounjougou, Mali
}

\author{
Louis De Weyer ${ }^{1,2}$ \\ 1. UMR 7041, Anthropologie des Techniques, des Espaces et des Territoires au Pliocène et au Pléistocène \\ (ArScAn-AnTET), France. \\ 2. College of Sociology and Anthropology, Sun Yat-Sen University, Guangzhou, 510275, China. \\ Email: louis.deweyer@gmail.com
}

\begin{abstract}
:
Ounjougou stratigraphic sequence (Bandiagara, Dogon Country, Mali) is the most complete record in Western Africa for the Middle Pleistocene. This paper focuses on the lithic industry unearthed in the lowest levels of the sequence. Despite the impossibility to fix the dating of those layers, the assemblage clearly presents Oldowan features. A strong erosive process, combined to the absence of Acheulean industry, strengthens the idea of a probable ancient age for the lithic industry. Morphometric, Technological and techno-functional approaches were performed to study sandstone polyhedrons, spheroids and bolas, abundant in the collection, along with a flake production on quartz and quartzite pebbles.

This study demonstrates that polyhedrons, spheroids and bolas were shaped from independent chaînes opératoires to realize specific tasks. The hypothesis of opportunistic knapping does not fit with these materials at Ounjougou. The evidence of shaping is highlighted by diacritic schemes showing that the flakes detached are not controlled for their usability, but for shaping the morphology of the spheroid. Apart from those polyhedrons and spheroids, flake production is also identified. While the shaping process is made on sandstone cobbles, sharp flakes are produced from quartz pebbles. This clear choice of different raw materials to produce shaped heavy tools in one hand and light flake tools in another hand strengthens the idea of a deliberate shaping of spheroid tools.

The discussion compares this assemblage with other known assemblages like Ain Hanech and Olducai Gorge. Our point focus on the methodology used to study these specific artefacts, very different from one author to another. We stress out the fact that using the term 'polyhedron' is not accurate to define artefacts that can refer to shape tools or multifacial cores. We suggest to avoid using it and to focus on a technical identification to name the artefacts as cores or tools. The technological and techno-functional approaches are relevant to make this distinction.

Then we propose some hypothesis about the use of spheroid and bolas and suggest experiments and traceological analyses in the future to confirm their functionality.

Ounjougou lithic tool kit, composed of flake débitage, retouched flakes and shaped tools on pebbles, along with the spheroids and bolas component, gives an evidence of a diversified tool kit corresponding to the Oldowan Industrial Complex, and then represents the first Early Stone Age site in stratigraphy in Western Africa.
\end{abstract}

Published by the School of History, Classics and Archaeology, University of Edinburgh ISSN: 2055-0472. URL: http://journals.ed.ac.uk/lithicstudies/

This work is licensed under a Creative Commons Attribution 2.5 UK: Scotland License. 
Keywords: Early Stone Age; lithic technology; polyhedrons, spheroids and bolas; Western Africa; techno-functional approach

\section{Introduction}

The Ounjougou complex has yielded the longest stratigraphic sequence for the Middle and Upper Pleistocene ever discovered in Western Africa.

A very rich accumulation has been highlighted, composed of archaeological levels from the Middle Stone Age to historic periods. Under those levels, the deposits in contact with the bedrock delivered an older testimony of human presence in the Western African subcontinent. This industry is characterized by a simple flake débitage associated with tools on cobbles, polyhedrons and faceted spheroids. Although these levels were not dated, a terminus ante quem of $150 \mathrm{ka}$ is given by an OSL date of the upper levels (Soriano et al. 2010). Besides, the geological context and the Oldowan-like typology of the assemblage involve a probable ancient age for this industry, and then question our knowledge of the first settlement in Western Africa.

The high degree of soil acidity, very common in Western Africa, reduces the archaeological record to the lithic materials only. Nevertheless, for the first time in this region, such an old occupation is discovered in stratigraphy, which represents an important step for the research in this area. Indeed, this lack of data also affects the Middle Stone Age (McBrearty \& Brooks 2000). It can be related with the difficulty to find stratigraphic sequences in this region as well as the relative depleted research in this area (Robert et al. 2003). Surface finds such as handaxes, cleavers and choppers are actually long known in SubSaharan Africa (Aumassip \& Chaïd-Saoudi 2004; Bayle des Hermens 1975; Clark 1982), but dating them remains impossible.

In this paper we present the analysis of the lithic materials from the lowermost layer of Ounjougou, using a technological and techno-functional approach, in order to develop comparisons with the Oldowan archaeological record from Eastern and Northern Africa.

\section{Site location and sedimentary context}

\subsection{Geographic and geological framework of Ounjougou complex}

Ounjougou is located in the Dogon Country, on the Bandiagara plateau, $12 \mathrm{~km}$ East from Bandiagara city (Figure 1). This open air site complex is scattered on a 10 square kilometres area, around four water streams. The main river, the Yamé, is an affluent of the Niger River.

In the mid 1930's, a sudden diversion in the course of the river Yamé induced a deep incision of the Holocene and Pleistocene sediments, revealing an important archaeological potential (Lespez et al. 2008; Rasse et al. 2006). Nowadays, evidences of occupations from the Paleolithic, Neolithic and Protohistoric periods appear along the thousands of meters of natural profiles, sometimes more than 10 meters high (Huysecom et al. 2004; Rasse et al. 2004; Soriano et al. 2010).

\subsection{Ounjougou stratigraphic sequence}

Ounjougou stratigraphic sequence provided a thick Pleistocene stratigraphy. The deposits come from two main origins: the disaggregation of the sandstone substrat (coarse sands and gravels) and aeolian deposits (fine-grained silts). Through time, the material has been reworked by colluvial and alluvial processes (Rasse et al. 2004; Soriano et al. 2010). The 
hydrological variations of the course of the Yamé occurred repeatedly and incised the different formations. Then, fine aeolian silts and coarse gravels interlock along the sequence.

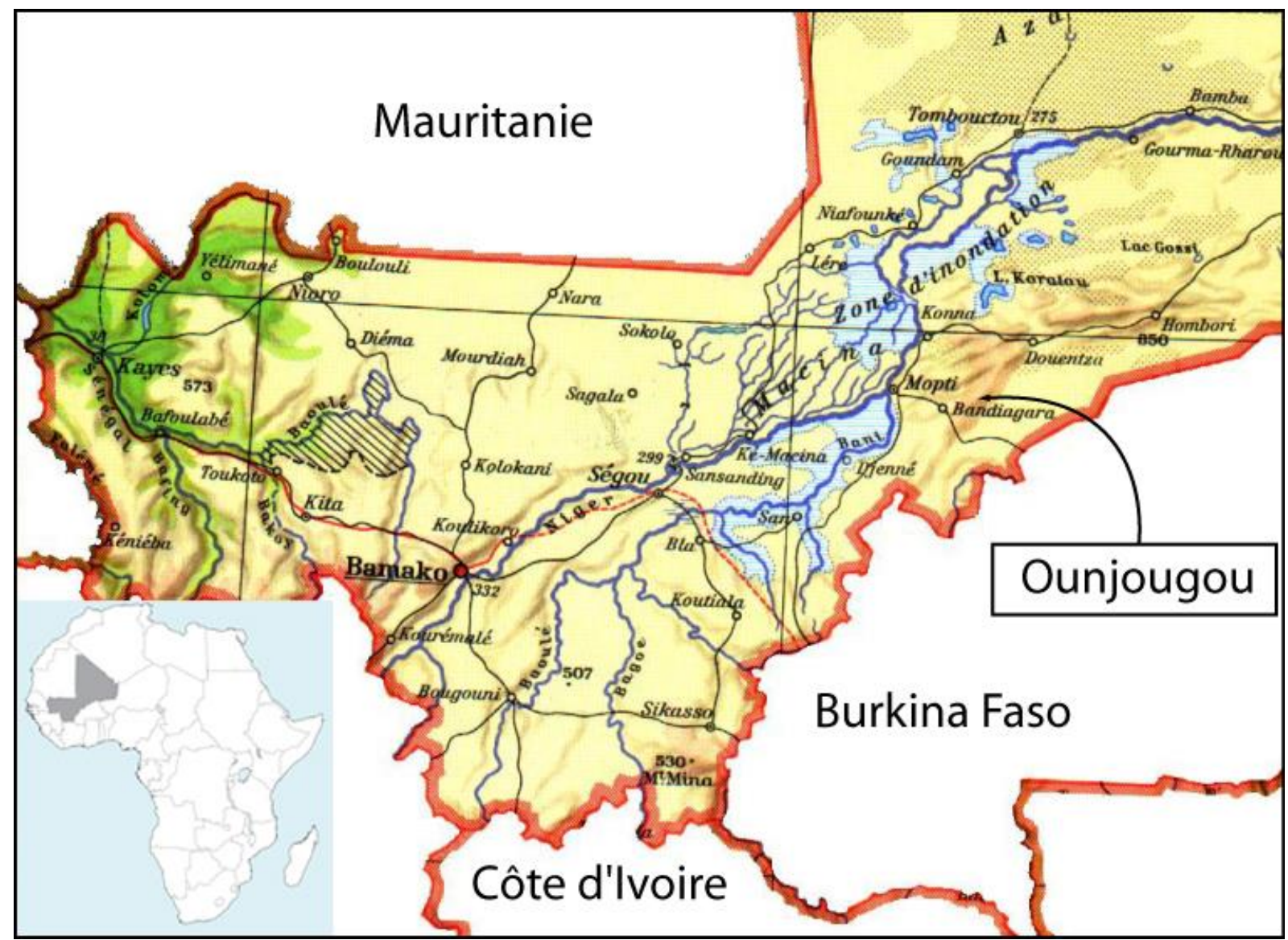

Figure 1. Location of Ounjougou complex.

Seven stratigraphic units were individualized, U1 (the oldest) to U7 (Figure 2). This sedimentary record cannot be considered as continuous, as several erosive processes were identified and created important hiatuses separating the units, especially for the oldest part of the sequence. The U1 and U2 units only appear in the deepest ravines outcrops, and an important sedimentary hiatus is separating U2 and U3, showing a significant erosion followed by the development of a soil horizon before deposition of U3. These sedimentary discontinuities were also observed between U3/U4, and U4/U5.

The sequence was finely analysed through systematic OSL dating combined with a geomorphological analysis of the formations. These deposits are dated between OIS 5 and OIS 2, with a refined record for OIS 3 (U3 to U5). The Upper Pleistocene sequence delivered 25 archaeological horizons during OIS 3, giving a very high resolution for the 100 to $30 \mathrm{ka}$ timescale (Figure 3).

Unit 2 is associated with OIS 5, with an OSL dating of around $150 \mathrm{ka} \mathrm{BP}$. The underneath levels were not the object of any OSL sample, due to the highly coarse-grained component of the deposits. 

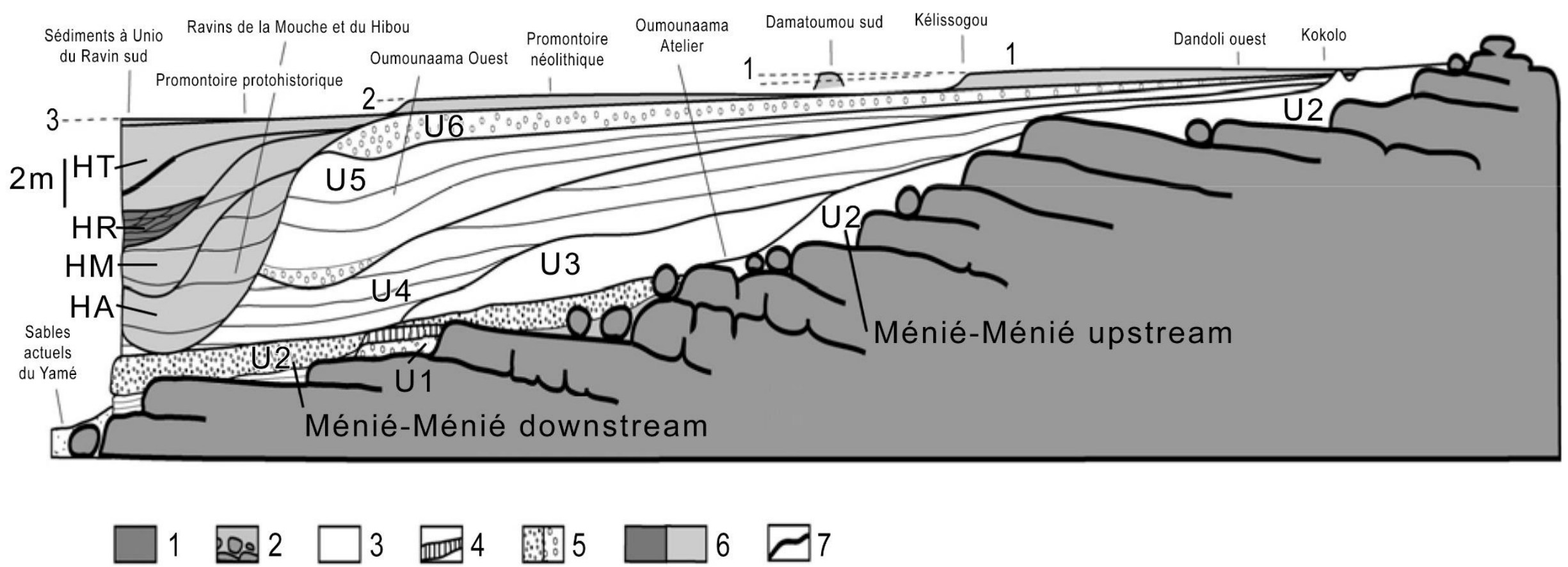

Figure 2. Synthetic profile of Ounjougou stratigraphic sequence (modified from Rasse et al. 2004). 1. Sandstone; 2. Arenaceous sandstone; 3. Pleistocene formations; 4. Iron duricrust; 5. Coarsed alluvial deposits; 6. Holocene formations. Abbreviations: HA - Early Holocene; HM - Middle Holocene; HR - Late Holocene; HT - Final Holocene); 7. Crust. 

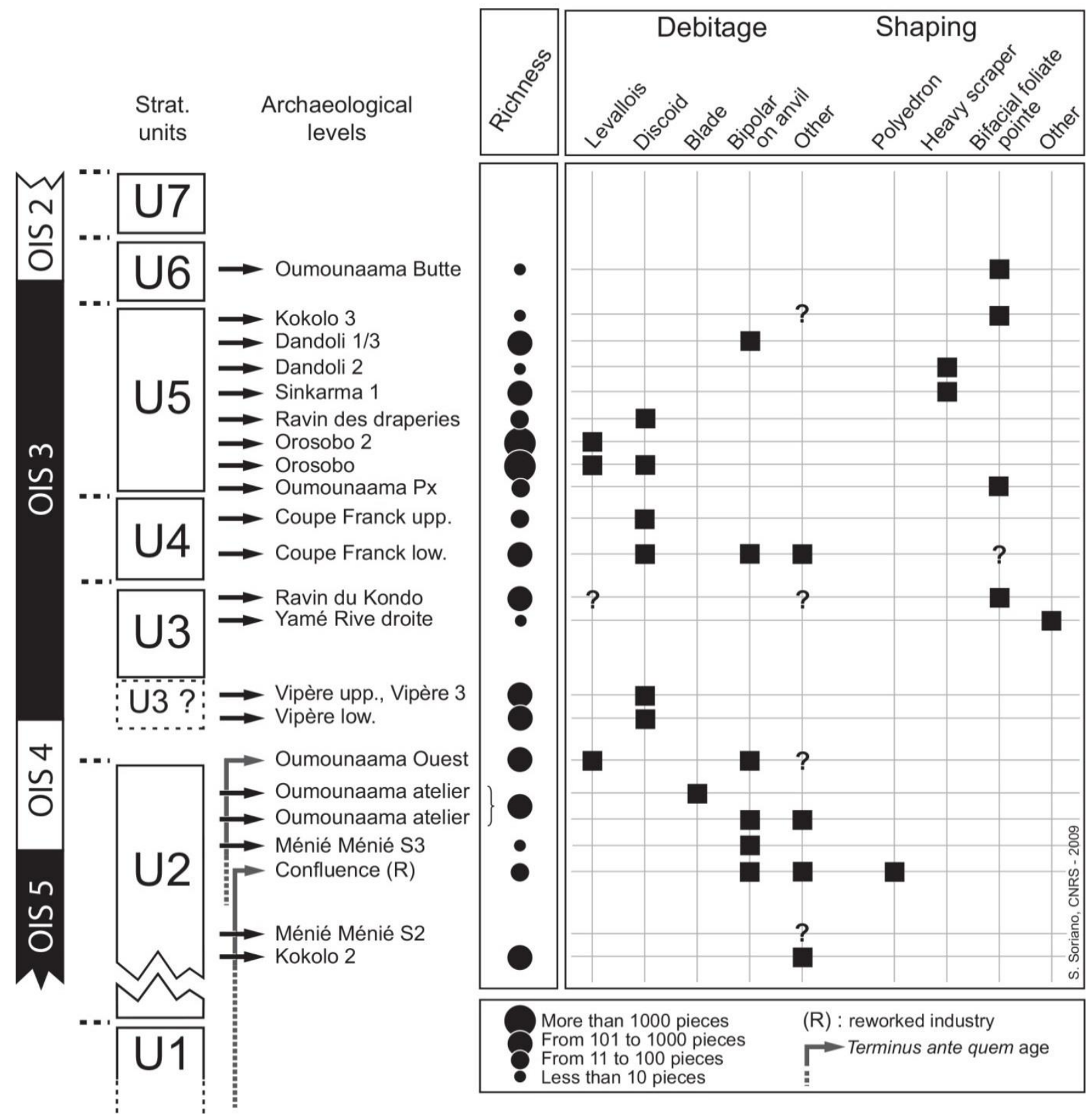

Figure 3. Schematic stratigraphic sequence of Ounjougou (from Soriano et al. 2010).

The artefacts appear into the oldest sedimentary deposits of Ounjougou sequence, U1 (Soriano et al. 2010). This unit was identified from the course of the Ménié-Ménié River to the Confluence sector (Figure 4). It is composed of indurated if not cemented sandy-silty gravels of heterogeneous size. Those sediments are preserved in small portions, in the form of compact and coarse patches adhering to the bedrock. At this location the bedrock presents a very developed alteration, defined as a typical arenaceous product (Soriano et al. 2010). This weathering is absent elsewhere when the bedrock is in contact with other sedimentary units (U2 or later units) (Figure 5). In this case it appears fresh, probably washed from its previous alterations. The Ménié-Ménié U1 deposits provided the biggest quartz and quartzite pebbles, with also sandstone pebbles exclusive to this sedimentary unit, that give evidence of a high intensity of fluviatile output that had never been reached in later periods. Lithic artifacts were observed and collected in situ from U1 at Ménié-Ménié and the left bank of the Confluence, as long as the deposits were preserved. 


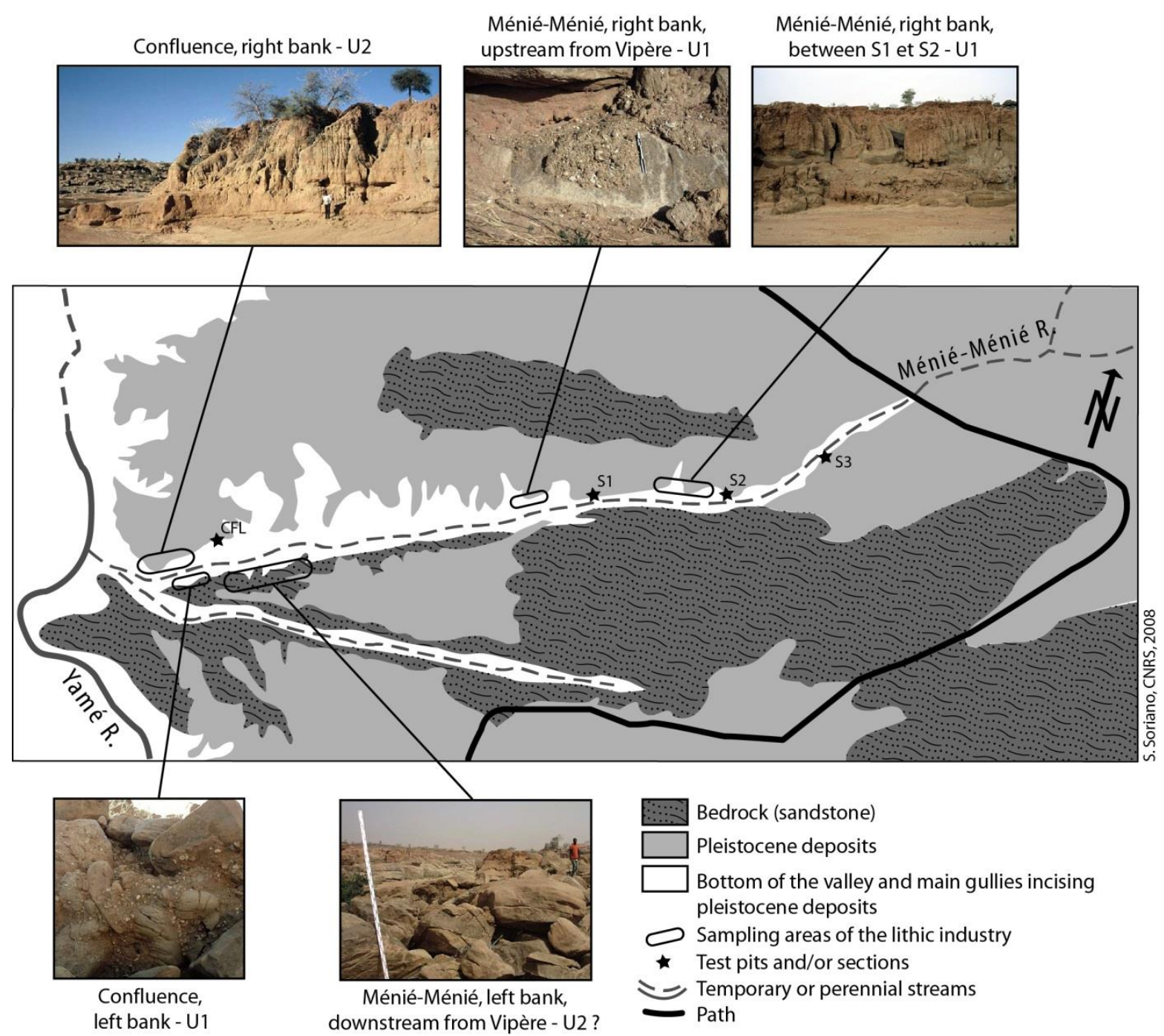

Figure 4. Map of the Ménié-Ménié sectors where the lithic industry has been sampled (Courtesy Sylvain Soriano, Mission archéologique Ounjougou).

Polyhedrons were also collected on the right bank of the Confluence, from cemented sandy gravels, but they cannot be related to U1, because of the sedimentary features. A silty level at its base was dated by OSL between 60 and $80 \mathrm{ka}$ (Tribolo et al. 2015), suggesting that this sandy gravel conglomerate is including U1 reworked deposits. The polyhedrons are then in a secondary position, attributed to U2 (Figure 5c).

Some U1 deposits were also identified at Dandoli Ouest, where artifacts were also collected. Apart from U1, some lithic materials also appeared in relation to hardened coarsegrained patches adhering to the bedrock (Dandoli Ouest, Ravin Sud, Ménié-Ménié) or from dismantled products of these patches (Ravin de la Vipère, Damatoumou Sud, Oumounaama) (Figure 6).

The coarse gravel aspect of the U1 sedimentary unit did not allow any attempt of OSL dating. Nevertheless, a terminus ante quem around $150 \mathrm{ka}$ was given by the OSL dating of U2 deposits in the section S1 (Figure 5a). The time gap between U1 and U2 is hard to evaluate, but the bedrock was washed from its alterations almost everywhere in the Ounjougou area, suggesting a long gap. The bedrock weathering in contact of U1, a typical arenaceous process, gives elements to identify long periods of washing under humid and warm conditions (Rasse et al. 2004). Some sandstone artifacts also present features of chemical alteration. Then, those deposits could objectively represent an earlier time period (Soriano et al. 2010). 

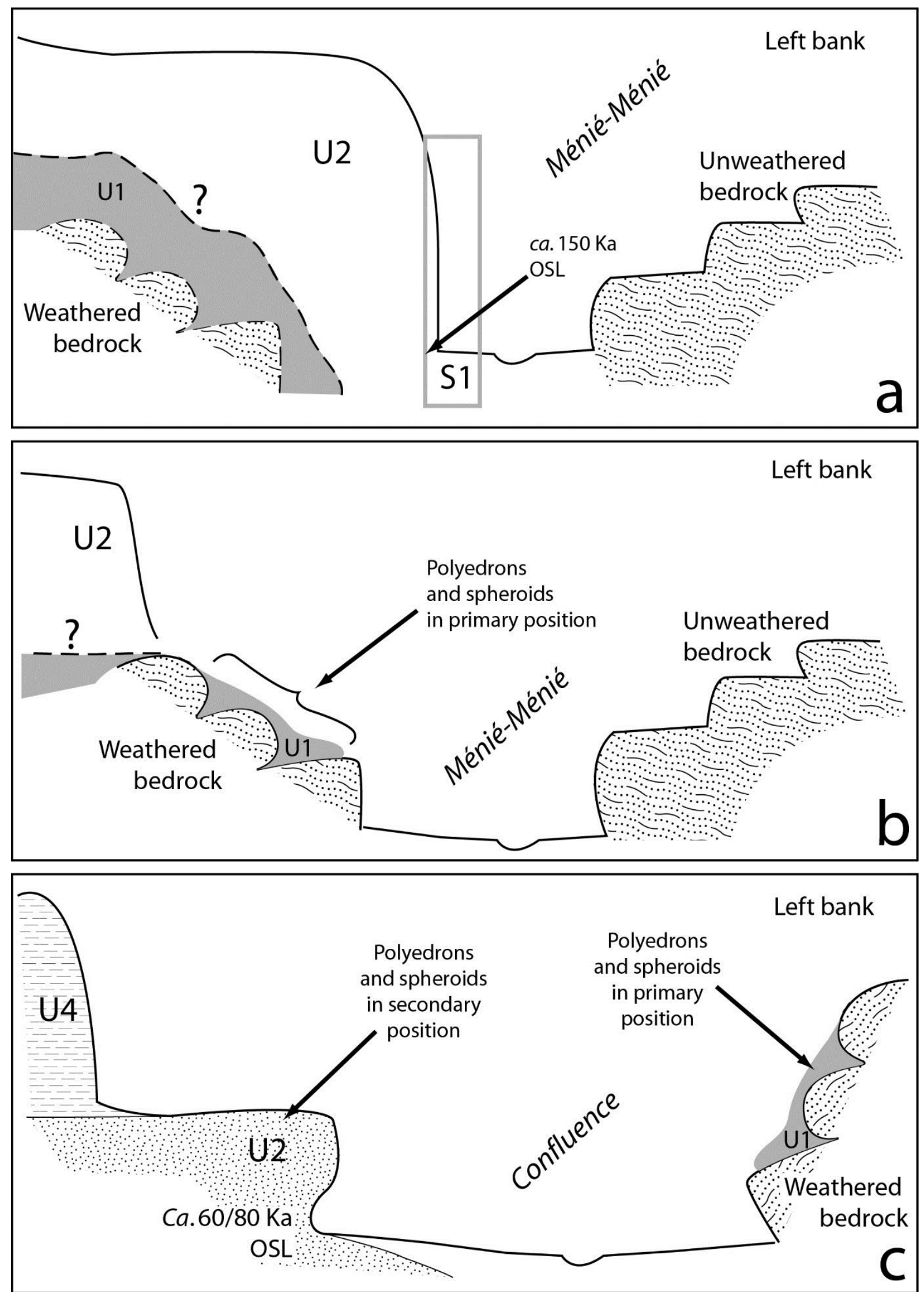

Figure 5. Synthetic profile of 3 sectors of the Ménié-Ménié, where lithic industry has been sampled (Courtesy of Sylvain Soriano, Mission archéologique Ounjougou). 


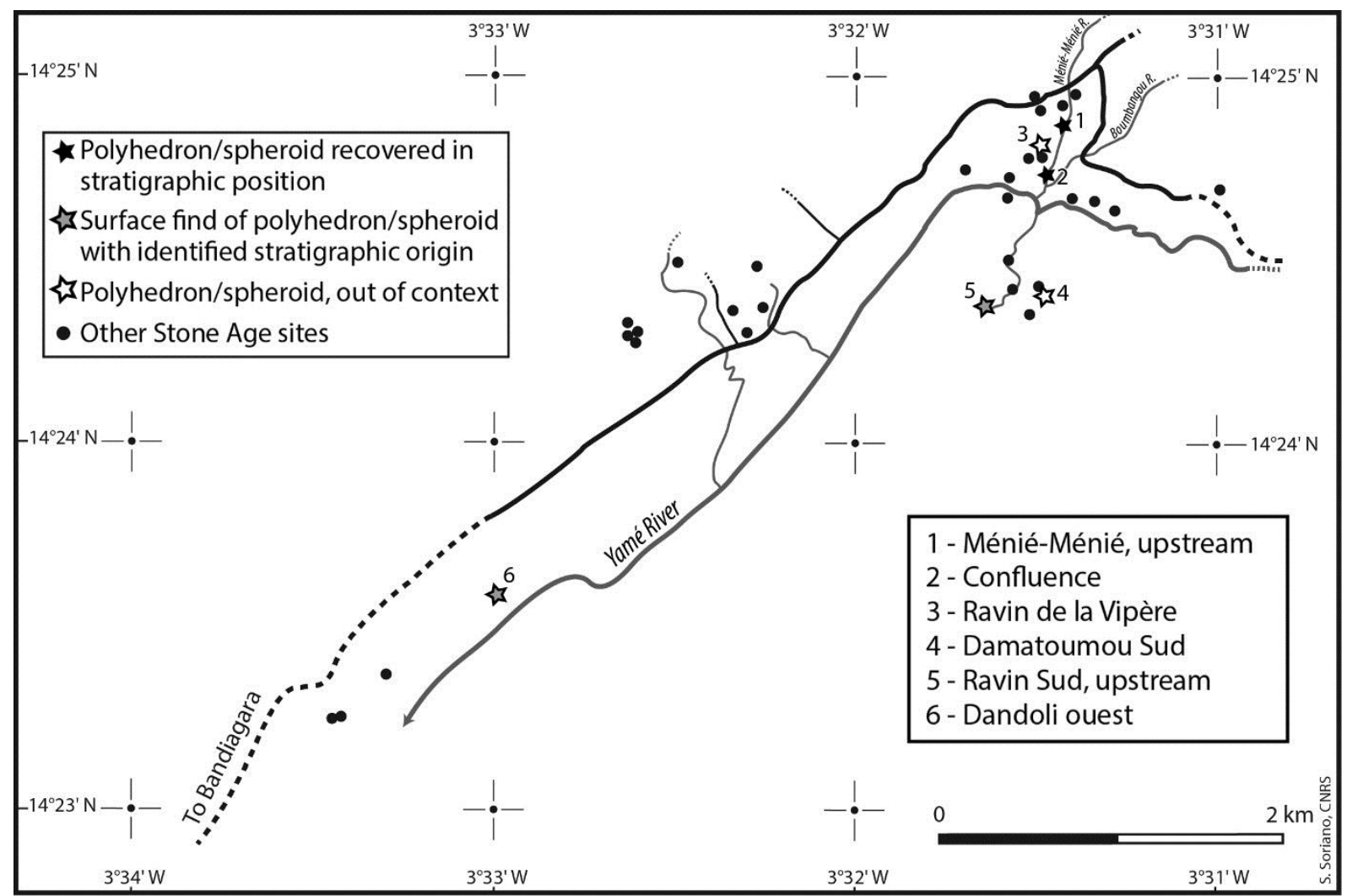

Figure 6. Location of all Paleolithic sites of Ounjougou complex (Courtesy of Sylvain Soriano, Mission archéologique Ounjougou).

Moreover, the Acheulean is completely absent at Ounjougou, although surface finds are well known in Western Africa (Aumassip \& Chaïd-Saoudi 2004). This also indicated the high probability of a profound hiatus between the oldest deposits containing polyhedron industry and the rich Middle Paleolithic record (Soriano et al. 2010).

\section{Materials and methods}

This paper focuses on the materials recovered from units $\mathrm{U} 1$ and $\mathrm{U} 2$, and our purpose is to characterize the assemblage by a technological approach, describing the chaines opératoires and the objectives of the production, in order to obtain elements to compare with the dated archaeological record.

\subsection{Taphonomy}

Although the assemblage is not abundant (94 pieces), a diversity of chaînes opératoires and endproducts is observed. A flake production is associated with macro-tools shaped on cobbles, and a production of polyhedrons, spheroids and bolas. Those last ones will be further described in the present paper.

The lithic industry was collected during several surveys of the Confluence and MéniéMénié area (Table 1). Some spheroids and polyhedrons were also collected from other localities of the site complex (Damatoumou, Oumounaama, Ravin de la Vipère). Most if not all the artifacts are associated with coarse fluvial deposits then they have been moved from their original position. Some artifacts are in fact moderately to intensively water worn and two heavily weathered cores were excluded from our analysis. This geological context also implies that a natural size sorting occurred and that the smallest component of the industry is 
lacking. This taphonomic bias has already been documented at Ounjougou for a Holocene industry also recovered from fluvial sandy gravels (Soriano \& Huysecom 2012).

Table 1. Lithic assemblage collected in U1 and U2 at Ounjougou complex. Abbreviations: * - In these sites, only polyhedrons and spheroids were sampled.

\begin{tabular}{lccccc}
\hline & $\begin{array}{c}\text { Polyhedrons, } \\
\text { spheroids and } \\
\text { bolas }\end{array}$ & $\begin{array}{c}\text { Cores } \\
\text { Flakes }\end{array}$ & $\begin{array}{c}\text { Heavy- } \\
\text { duty } \\
\text { tools }\end{array}$ & $\begin{array}{c}\text { Total } \\
\text { pieces }\end{array}$ \\
\hline $\begin{array}{l}\text { Confluence, right bank, red sandy } \\
\text { gravels U2 (secondary position) }\end{array}$ & 7 & 5 & 12 & 3 & 27 \\
$\begin{array}{l}\text { Confluence, left bank, U1 } \\
\text { Ménié-Ménié, left bank Viper } \\
\text { downstream, U2 }\end{array}$ & 1 & 0 & 2 & 1 & 4 \\
$\begin{array}{l}\text { Ménié-Ménié, right bank, Viper } \\
\text { upstream, U1, downstream S1 }\end{array}$ & 1 & 4 & 18 & 7 & 33 \\
$\begin{array}{l}\text { Ménié-Ménié, right bank, Viper } \\
\text { upstream U1, between S1 and 2 }\end{array}$ & 1 & 0 & 0 & 1 & 2 \\
$\begin{array}{l}\text { Dandoli West* } \\
\text { Damatoumou South* }\end{array}$ & 7 & 8 & 9 & 0 & 18 \\
$\begin{array}{l}\text { Viper Ravine* } \\
\text { Total }\end{array}$ & 2 & & & & 7 \\
\hline
\end{tabular}

\subsection{Polyhedrons, spheroids and bolas}

An important component of this assemblage comprises polyhedrons, spheroids and bolas. Those artefacts are well known during the Palaeolithic, but always raise the issue of their technical nature and purpose. This production has to be very cautiously analysed, regarding the on-going debate around these artefacts.

\subsubsection{A messy typology}

From the last century, scholars pointed out these artefacts as something else than the classical cores and pebble-tools usually encountered in the archaeological record, but the issues of what they are and their intended purpose are still debated and hardly find a single answer (Arambourg 1950; Balout 1955; Isaac 1976; Jones 1994; Leakey 1971; Mora \& de la Torre 2005; Sahnouni et al. 1997; 2002; Texier \& Roche 1995; Toth 1985; Willoughby 1987).

M.D. Leakey's classification of Olduvai Gorge (Tanzania) assemblages was based essentially on typological grounds, including sometimes functional observations (Leakey 1971: 3-8). In fact, polyhedrons, spheroids and bolas (PSB) are scattered into several typological categories, such as hammerstones, cores, utilized materials, manuports, including natural artifacts imported to the site, using morphological criteria. From the typological identification of the PSB arise another interest: the technical processes to produce them. The study of Isenya (Kenya) $700 \mathrm{Ka}$ old Acheulean assemblage gave researchers the opportunity to test the hypothesis of a single reduction process to produce spheroids (Roche \& Texier 1991; Texier \& Roche 1995). Comparing the artifacts of Isenya with replications, authors defined polyhedrons as an initial step of a spheroid shaping chaîne opératoire, occasionally giving usable flakes, but always as by-products of a shaping process. At Isenya, flake production would be assumed by other core reduction methods. Although this hypothesis fits very well with Isenya industry, it does not necessary match with other assemblages. Indeed, 
the technical incompatibility between polyhedrons and spheroids was demonstrated at Olduvai (Jones 1994). First, Polyhedrons were produced on basalt and quartz, then spheroids only on quartz. Second, quartz polyhedrons at Olduvai show equals or lower dimensions than spheroids. Then it seems that in this case polyhedron production can hardly be related with spheroid shaping chaîne opératoire. On the other hand, P.J. Texier and H. Roche stressed out that the shaping process of a spheroid implies to observe strictly very open knapping angles, and the reduction sequence would end as soon as a removal is too intrusive, leading to abandon the project or making something else (Texier \& Roche 1995).

Other researchers argue that the PSB are part of the same reduction sequence, but for the production of flakes. This kind of débitage would correspond to a least effort strategy involving the anarchic exploitation of all suitable striking platform, explaining the progressive achievement of a spheroidal morphology (Schick \& Toth 1994). Experiments on limestone from Ain Hanech (Algeria) were conducted to test this hypothesis, with the only criteria to produce as long as possible usable flakes (Shanouni et al. 1997: 704). The results show that one can obtain the polyhedral and spheroidal morphology on a core by producing flakes.

This bibliographical review stresses the point that this kind of artifacts is complex, and may not represent the same reality from one site to another. Metrics, statistics, experiments, lithic technology, typology even combined all together do not afford the possibility to draw a universal definition of polyhedrons, spheroids and bolas. In this perspective, our purpose is to propose an effective approach to describe the technological features involved in the production and functionality of those artifacts in Ounjougou, and compare our results with assemblages from the Early Stone Age presenting a similar component. We decided to exclude the classical sub-spheroid class, because in our view it represent only a morphological classification, giving no sense to the technological role of each piece and even creating a confusion in the understanding of the reduction sequences described in this paper.

\subsubsection{Morphometric analysis}

We developed a morphometric analysis of the materials in order to understand the characteristics of each polyhedron, spheroid and bola, and reinforce each category. These data were completed by taking account of the number of removals in each piece.

The collection comprises 22 polyhedrons, spheroids and bolas. A high disparity is observed concerning the number of removal in each piece (Table 2), between 26 remaining removal scars and none (meaning that all scars were deleted by pecking, or that a naturally spheroid block was used).

Table 2. Number of removals, Length/Width and Length/Thickness ratio $(\mathrm{cm})$, for polyhedrons, spheroids and bolas.

\begin{tabular}{lcccc}
\hline & Polyhedrons & Spheroids & Bolas & Total \\
\hline Number of pieces & 8 & 6 & 8 & 22 \\
Minimum number of removals & 16 & 8 & 0 & 0 \\
Maximum number of removals & 26 & 25 & 20 & 26 \\
Average number of removals & 19.88 & 18.67 & 11.38 & 16.45 \\
Standard deviation & 3.04 & 5.75 & 6.67 & 6.44 \\
Average of the Length/Width ratio & 1.09 & 1.05 & 1.03 & 1.06 \\
Standard deviation of the Length/Width ratio & 0.07 & 0.03 & 0.03 & 0.04 \\
Average of the Length/Thickness ratio & 1.19 & 1.11 & 1.07 & 1.12 \\
Standard deviation of the Length/Thickness ratio & 0.09 & 0.04 & 0.06 & 0.06 \\
\hline
\end{tabular}


Spheroids show never more than 15 negatives, and an intense pecking activity is observable on several pieces, that make scars disappear, until leaving no edges at all sometimes (bola). Those artifacts are clearly shaped, as any of the last reduction operation leaves a usable flake. Those artifacts are made to be tools, but the question of their function is problematic and will be discussed below.

Another issue appears regarding the pieces with more negative scars. Several morphologies exist and imply several chaînes opératoires. Polyhedral pieces do not show any features of spheroid shaping, though spheroids are shaped intentionally.

The morphometric analysis (Table 2, Figure 7) reveals a homogeneous distribution of the Length/Width rate for all the PSB (Polyhedrons, Spheroids and Bolas). The variability is however much more remarkable concerning the Length/Thickness rate: highly heterogeneous for the polyhedrons, homogeneous for the spheroids and bolas.

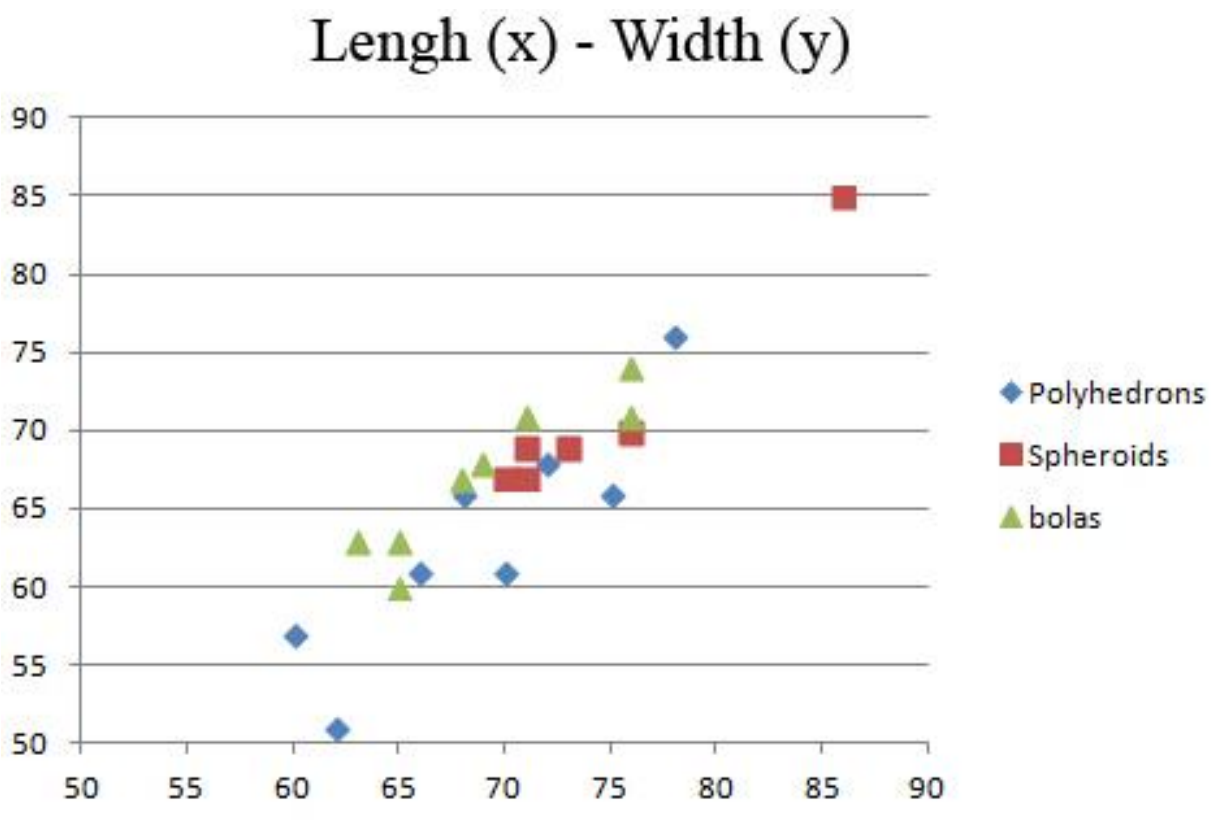

Lengh (x) - Thickness (y)

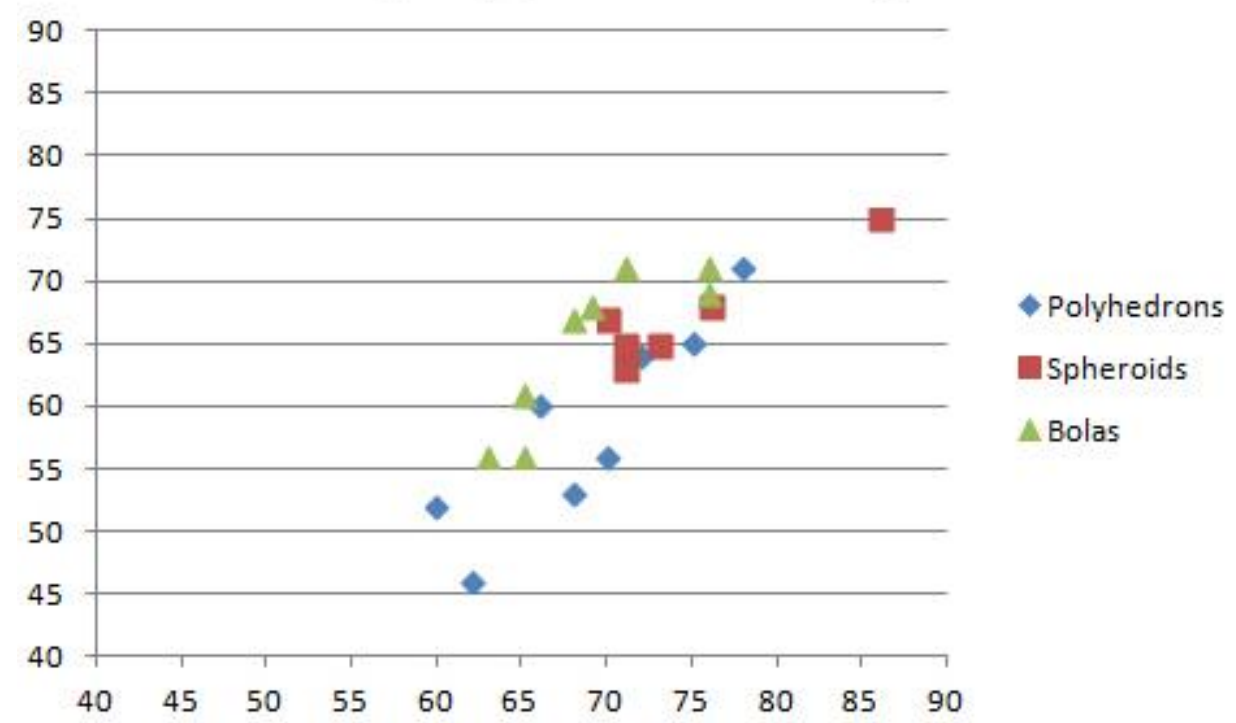

Figure 7. Length (x) / Width (y) on the left and Length (x) / Thickness (y) on the right ratio for each category (mm). 
The results obtained from the morphometric analyses, more than confirming a morphological classification, also highlights that spheroid volumes are very homogeneous, as well as their dimensions (except for one of them Figure 7), reinforcing the hypothesis that they were shaped intentionally. Moreover, polyhedrons are characterized by a high dimensional variability, and a majority of them are smaller than the spheroids (Figure 7). That strengthens the idea of two distinct chaînes opératoires, and also suggests that inside the polyhedron type itself, several operative schemes exist.

\section{Results}

\subsection{Technical analysis}

Then, new issues appeared from this morphometric analysis. How and why have spheroids and bolas been shaped? How to characterize the polyhedrons? Are they a single type of artifact or several kinds of cores or tools? To answer those questions, we performed a technical analysis, using diacritic schemes and techno-functional analysis to understand the objectives of the production, the functional potentials of the tools produced and try to define the technical role of the PSB in this assemblage.

Concerning the blanks, the polyhedrons, spheroids and bolas documented in this assemblage were obtained from the selection of sandstone cobbles that may sometimes present naturally rounded surfaces, implying a selection of the cobbles. This is particularly clear for the bolas, but not systematic for the polyhedrons and spheroids. In this case, the knapping and shaping process is longer and implies preparation phases during the chaîne opératoire.

\subsection{Polyhedrons}

Polyhedron type is the most heterogeneous category sorted out by morphometric analysis. Indeed, diacritical schemes and technological analysis lead to recognize three different kinds of artifacts. One is an orthogonal core exploited on all its surfaces, and two different kinds of tools were also identified.

\subsubsection{Core}

The core-polyhedron presents a relatively cubic morphology. The reduction sequence consists in the exploitation of each surface by at least two distinct striking platforms, opposed or adjacent one to another. The polyhedral aspect is given by the continuous change of débitage surface, as seen by the order of removals (Figure 8). The flakes produced are quadrangular and elongated, and comprise the same characters than the quartz flakes produced on pebble cores described below.

\subsubsection{Tool-type 1}

The other polyhedrons are tools; Diacritic schemes lead to separate two operative schemes to produce two types of tools.

The first type (Figure 9) is characterized by an active part unshaped, showing percussion scars. Diacritic scheme analysis shows that the volume is created around this crushing active part, and the last removals reduce the volume adjacent to the active part. All the surfaces are shaped to help handling the tool and get the active part isolated from the hand, opposed to the palm where the tool is handled (Figure 9). Associated to this tool structure, the gesture must be vertical percussion. 

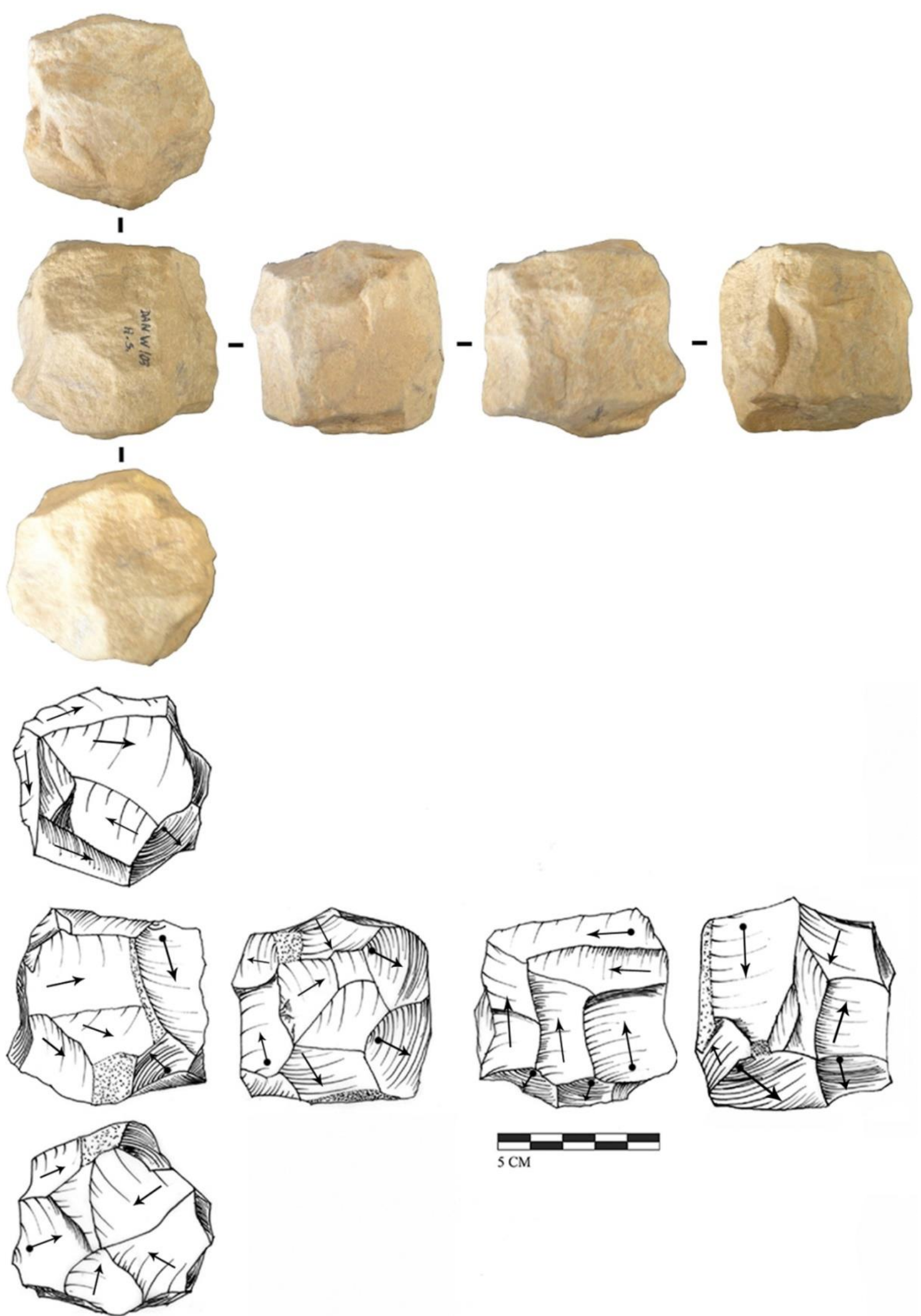

Figure 8. Core polyhedron. Quadrangular flake production on all faces of the core. 

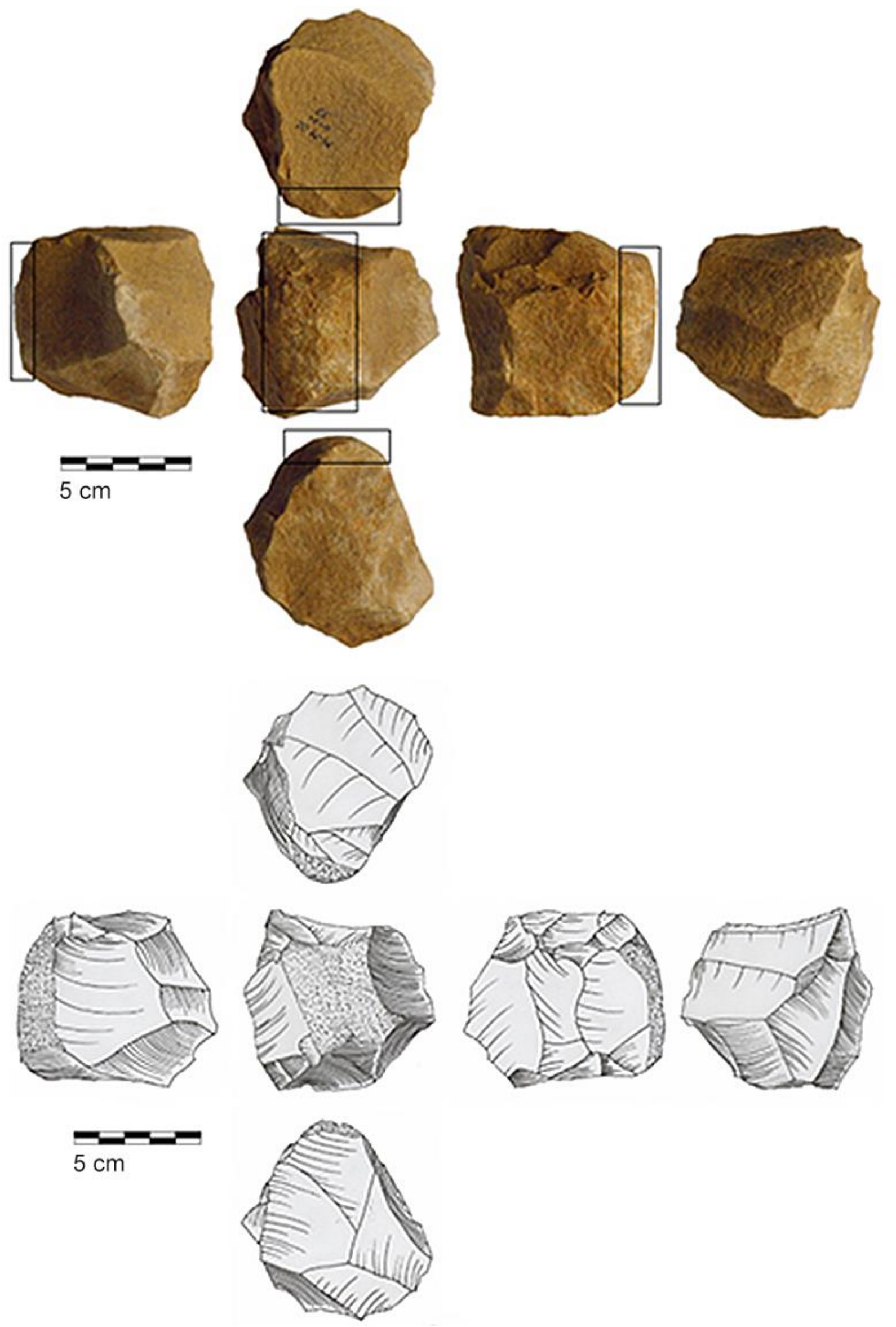

Journal of Lithic Studies (2017) vol. 4, nr. 1, p. Xx-xx 
Figure 9. Polyhedral tool with isolation of the transformative part by large abrupt removals all around.

\subsubsection{Tool-type 2}

Another tool type was identified. Diacritic scheme is helpful to understand the structure of the tool, and its production process (Figure 10). The shaping starts by the creation of a denticulated edge with long abrupt removals knapped from each part of this edge $\left(70^{\circ}\right)$. Then, opposed to this triangular section, a flat surface is shaped.

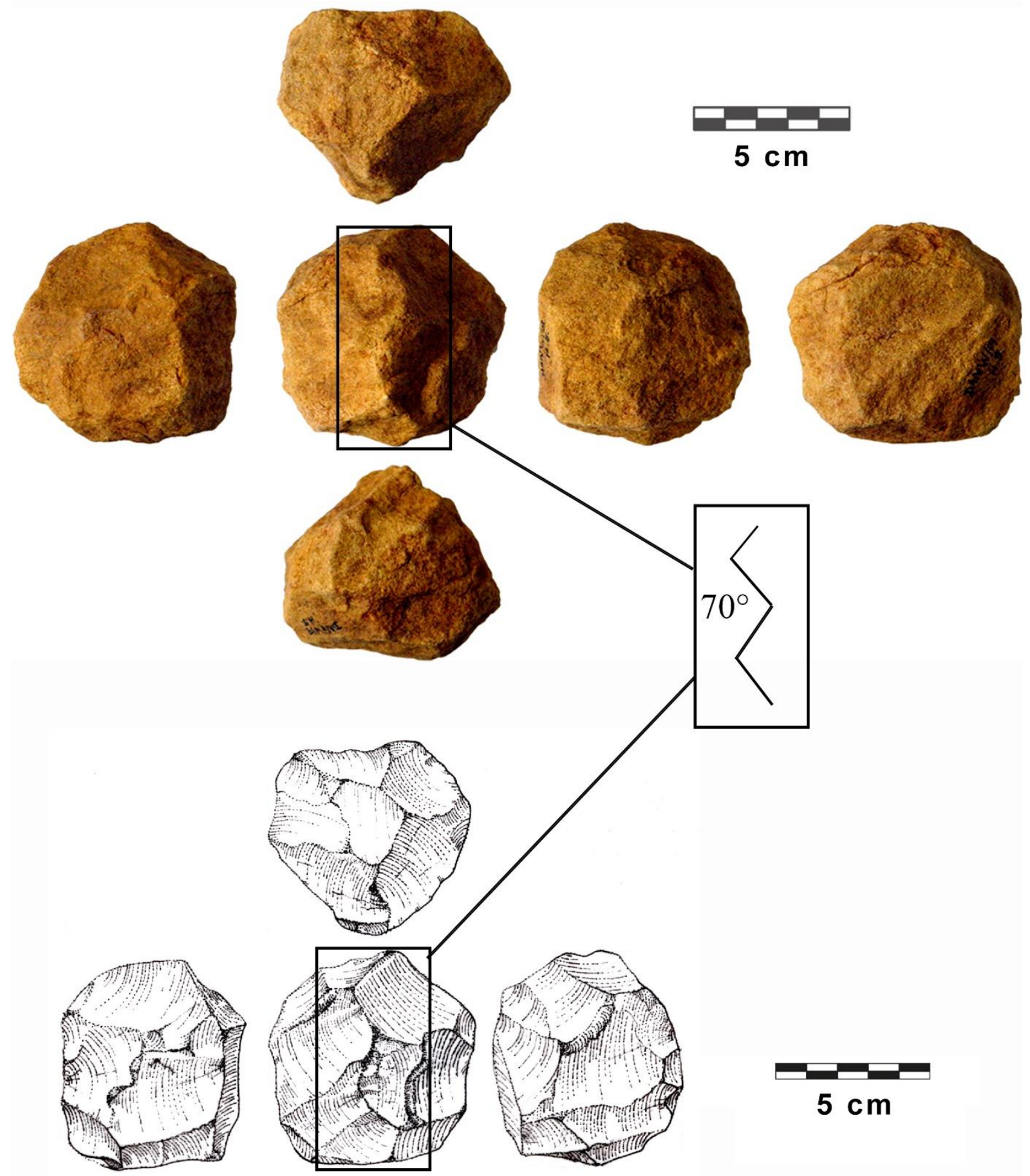

Figure 10. Polyhedral tool, shaping of a cutting edge opposed to a large handling part (Drawing by Amir Beshkani). Scale bars are $5 \mathrm{~cm}$ (divided into $1 \mathrm{~cm}$ sections). 
Percussion scars were observed in the denticulated edge, suggesting the same kind of gesture than the previous example.
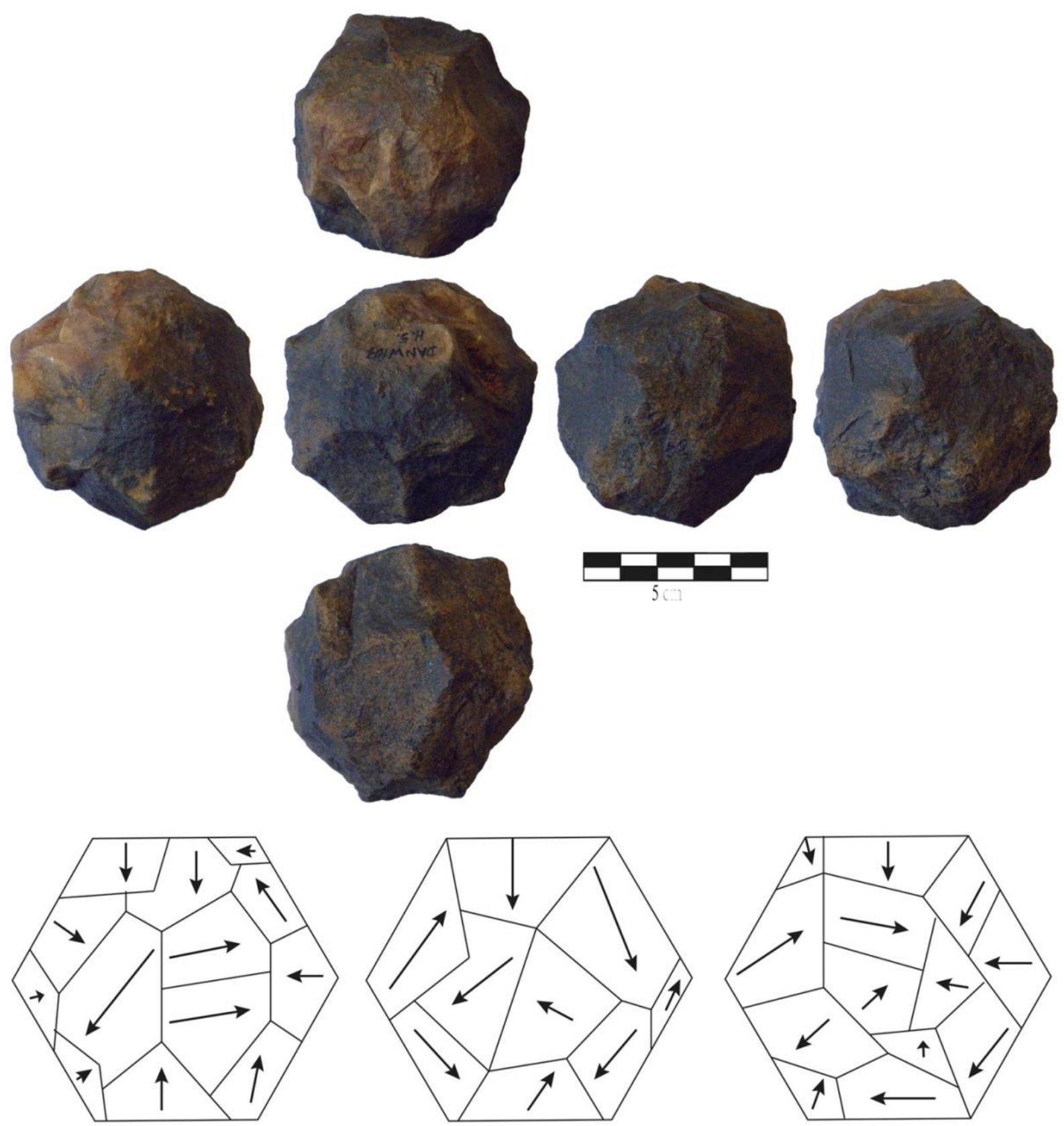

Figure 11. Diacritic scheme of a spheroid.

Although they present the same shaping structure, their active parts are different. The first type comprises natural rounded active parts (Figure 9). And the second involve a denticulated cutting edge (Figure 10). This may involve the same functionality (vertical percussion) for two different functions (for example, activities on different materials).

Using the technological approach combined to a techno-functional analysis allowed to identify several objectives concerning the polyhedrons, and led to discriminate a core and two independent tool structures, sharing the same structural shape. As a matter of facts, no link was established between those artifacts and the spheroids and bolas production process. 


\subsection{Spheroids and bolas}

\subsubsection{Chaînes opératoires}

The spheroids involve a volumetric shaping all around the block. Each step of the confection takes account of the final project. It is attested by the diacritic schemes (Figure 11). Connected series of removals hardly exceed 3 negatives on 2 adjacent faces. This is actually consistent with the hypothesis of a shaping of spheroid volumetric structures. Indeed, if the chronology of removals is very hard to follow, it is because the volumetric structure imposes to switch often from one striking platform to another in order to remove flakes from all the faces regularly.

The multiplicity of small series of removals linked together illustrates the objective to shape a spheroid object around a central point guiding the confection (Figure 11).

Diacritic schemes are ineffective to describe the bolas. Indeed, the crushing of all the edges makes the recognition of removal negatives practically impossible (Figure 12). Nevertheless, this crushing by pecking process is identifiable, at least on some parts of the bola (Figure 12).
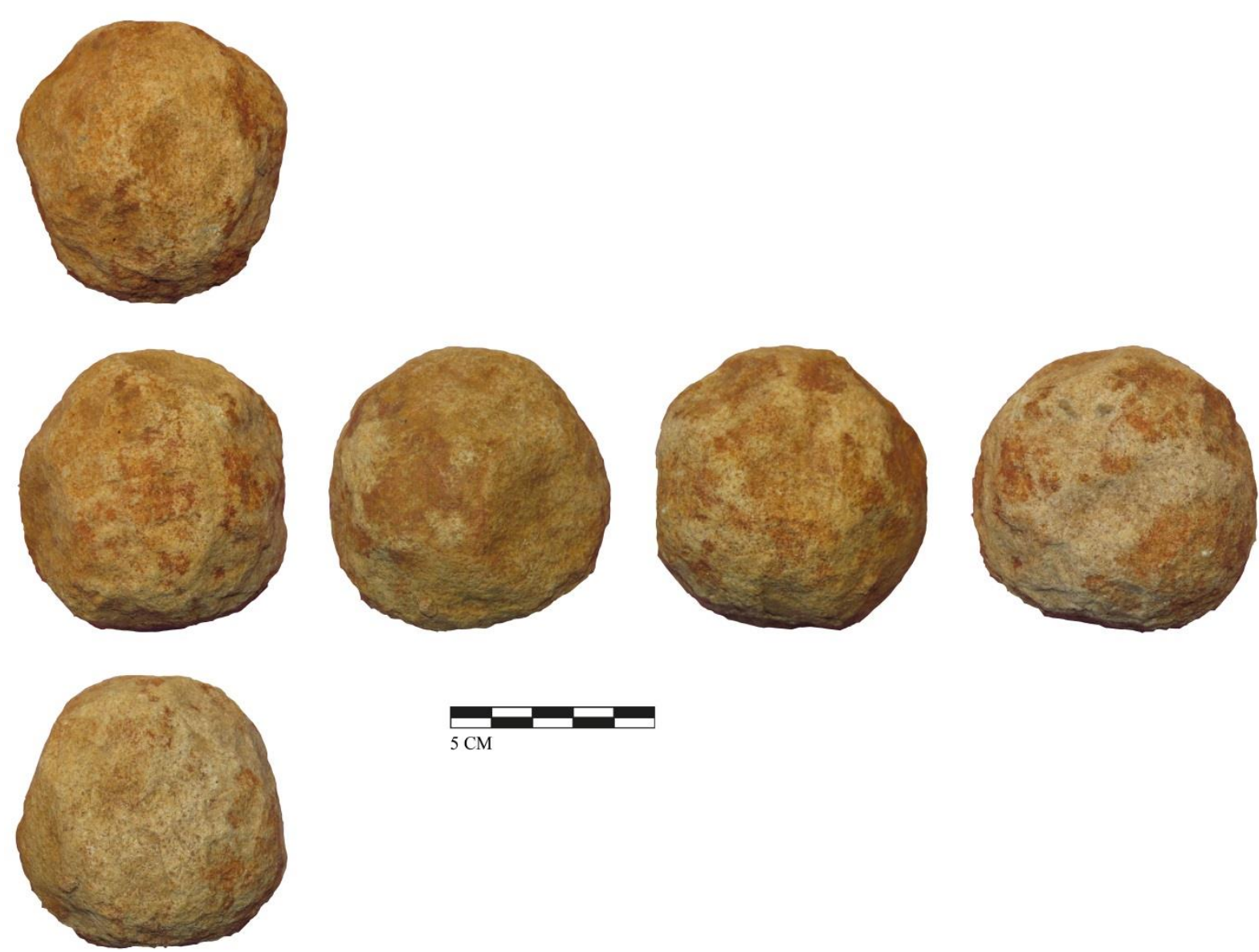

Figure 12. Bola. Percussion scars are almost completely deleted by crushing and pecking of the edges.

\subsubsection{Functional potentials}

Spheroids and bolas present a regular volume. No distinction can be made concerning the techno-functional units because by turns, each part of the piece plays the role of maintaining part and active part. If the functionality of spheroids and bolas seems to be very close, if not identical, a strong technical difference might suggest two specific functions. Indeed, the remaining edges on the spheroids form points all around the piece for many of them (Figure 
13). Then, pointed spheroids are distinguishable from faceted or smoothed spheroids and bolas in terms of function.

Several schèmes opératoires were identified from the PSB category, involving specific functionalities. Those artifacts were produced following specific chaînes opératoires, involving different functional projects. Their singularity is highlighted by the débitage and shaping activities completing Ounjougou assemblage.
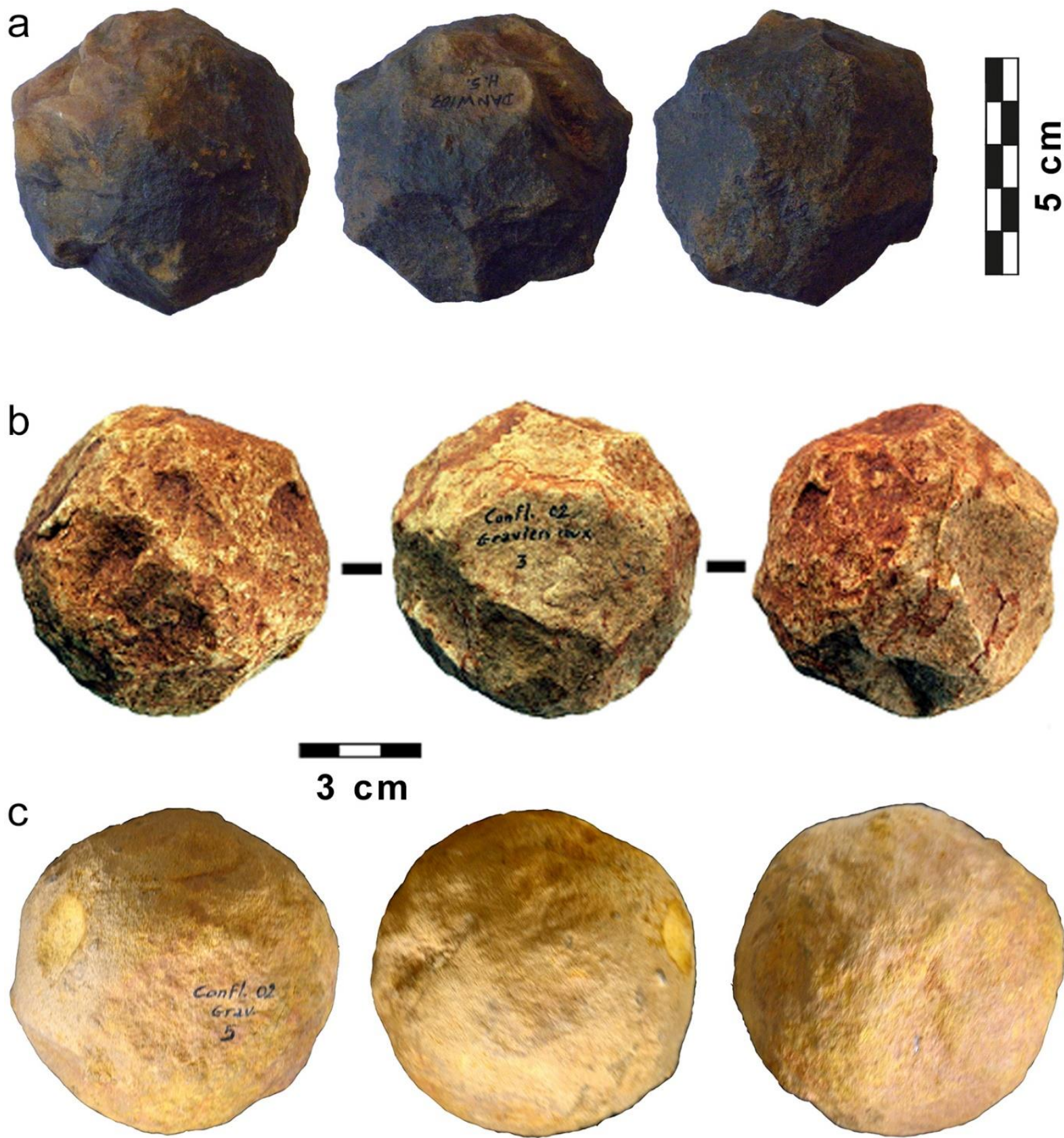

\section{$3 \mathrm{~cm}$}

Figure 13. Tools on spheroids and bolas. a. pointed spheroid; b. faceted spheroid; c. bola.

\subsection{Débitage}

\subsubsection{Cores}

Flake production was made essentially from quartz, quartzite and quartzite-sandstone pebbles (Table 3). Two cores on sandstone slabs were also collected. Reduction sequences are 
relatively short, with an average of six removals per core (Table 4). The reduction process is systematic. It consists first on the opening of a striking platform on one extremity of the pebble either by one or two thick removals (Figure 14, a; b) or sometimes with bipolar technique (Figure 14, c; d). Once the striking platform is opened, the core is exploited following the natural convexities of the pebble. Indeed, the flakes produced are mostly cortical or half-cortical.

Table 3. Number of cores.

\begin{tabular}{lc}
\hline Tested Pebble & 1 \\
Cores on Pebbles & 15 \\
Cores on Slabs & 2 \\
Indeterminate & 2 \\
\hline Total Cores & $\mathbf{2 0}$ \\
\hline
\end{tabular}

Table 4. Number of removals per core (Tested pebble and indeterminate excluded).

\begin{tabular}{lcc}
\hline & Core on Pebble & Core on Slab \\
\hline Number of cores & 15 & 2 \\
Average number of Removals & 6 & 14 \\
Maximum number of removals & 14 & 15 \\
Minimum number of removals & 3 & 13 \\
Standard deviation & 3 & 1,5 \\
\hline
\end{tabular}
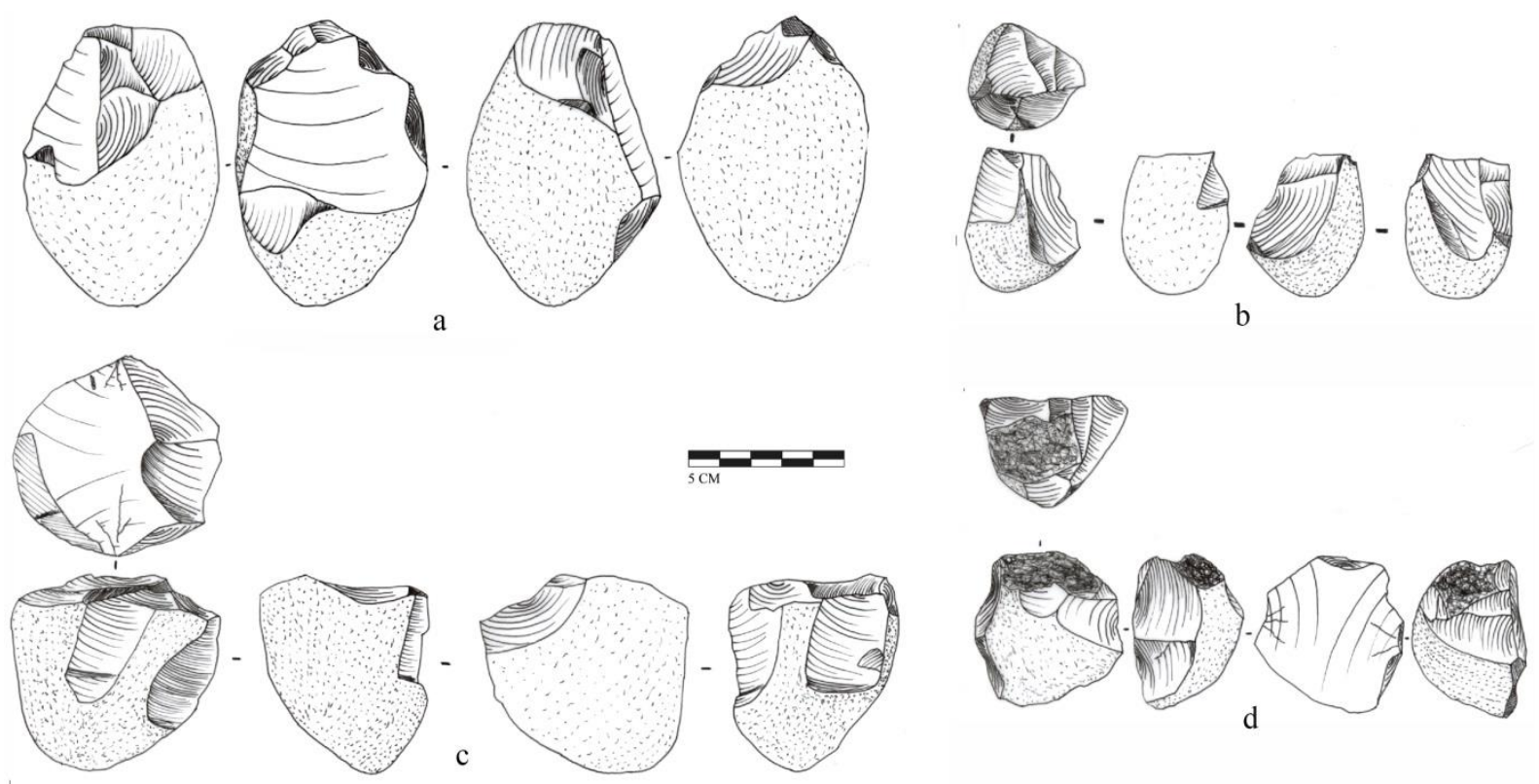

Figure 14. Cores on pebbles. (The scale bar is $5 \mathrm{~cm}$ wide, divided into $1 \mathrm{~cm}$ segments.)

The cores on slabs were more intensely reduced (Table 4). This can be explained by the use of large striking platforms (the flat faces of the slabs), that allow longer sequences without any change of flaking direction (Figure 15).

\subsubsection{Objectives of the debitage}

The production is dominated by elongated and quadrangular flakes (Figure 16), mostly cortical and half-cortical, regarding the low intensity of core reduction and the use of natural 
convexities. Partly cortical flakes cortex is especially located on one edge or on the distal extremity of the flakes, illustrating the role of natural convexities in the knapping strategies. Naturally backed flakes are also numerous, and illustrate the purpose of producing a cutting edge opposed to a back, mostly natural. Several Siret fractures were also identified (Table 5).

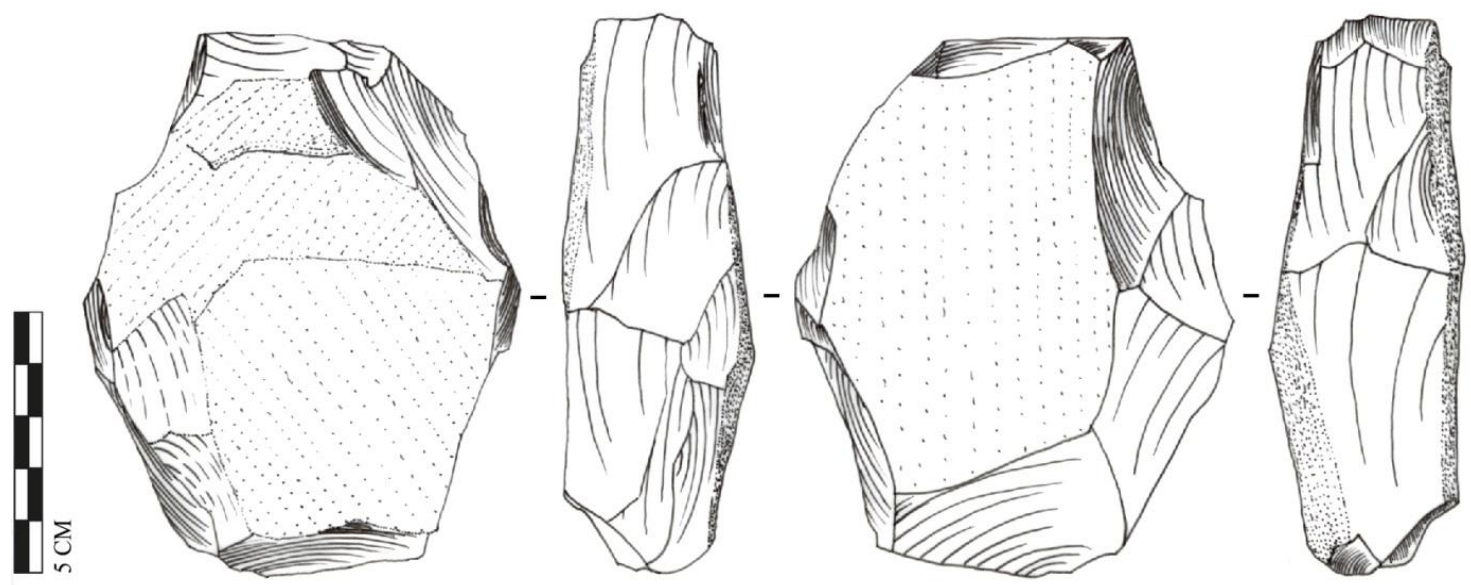

Figure 15. Core on slab.

Table 5. Number and type of flakes.

\begin{tabular}{lc}
\hline Cortical flakes & $\mathbf{4}$ \\
\hline Half-cortical flakes & 8 \\
Siret flakes & 7 \\
Débordant flake & 1 \\
Natural backed flakes & 4 \\
Whole flakes & 6 \\
Pebble fragment & 1 \\
Quadrangular slab & 1 \\
Indeterminate fragments & 11 \\
\hline Total Flakes & $\mathbf{4 4}$ \\
\hline
\end{tabular}

\subsection{Tool kit}

The assemblage comprises a component of modified, shaped or retouched tools. A division is observed between small tools $(\mathrm{n}=9)$ exclusively obtained from débitage, and heavy-duty tools $(\mathrm{n}=7)$, mostly produced through shaping, and at a lesser extend from débitage.

Small tools are characterized by two major structures: natural cutting edges opposed to modified cutting edges.

Unmodified endproducts present a side cutting edge opposed to a natural back (Figure 17, a). One flake got a modification of its back, with a regularization of the back, opposed to an unmodified cutting edge (Figure 17, b). A Siret fractured flake also presents a functional potential, with the same natural cutting edge opposed to a back structure (Figure 17, c).

Retouched cutting edges offer several functional potentials. One flake present the same features than the previous detailed flakes, but its cutting edge was modified by a short retouch process (Figure 17, d). Two notches on a side edge provided a prominent cutting edge isolated from the remaining edge of a flake (Figure 17, e).

Denticulated pieces were also produced, along the lateral cutting edge (Figure 17, f). An abrupt retouch opposed to the denticulation was observed on one flake (Figure 17, g). 

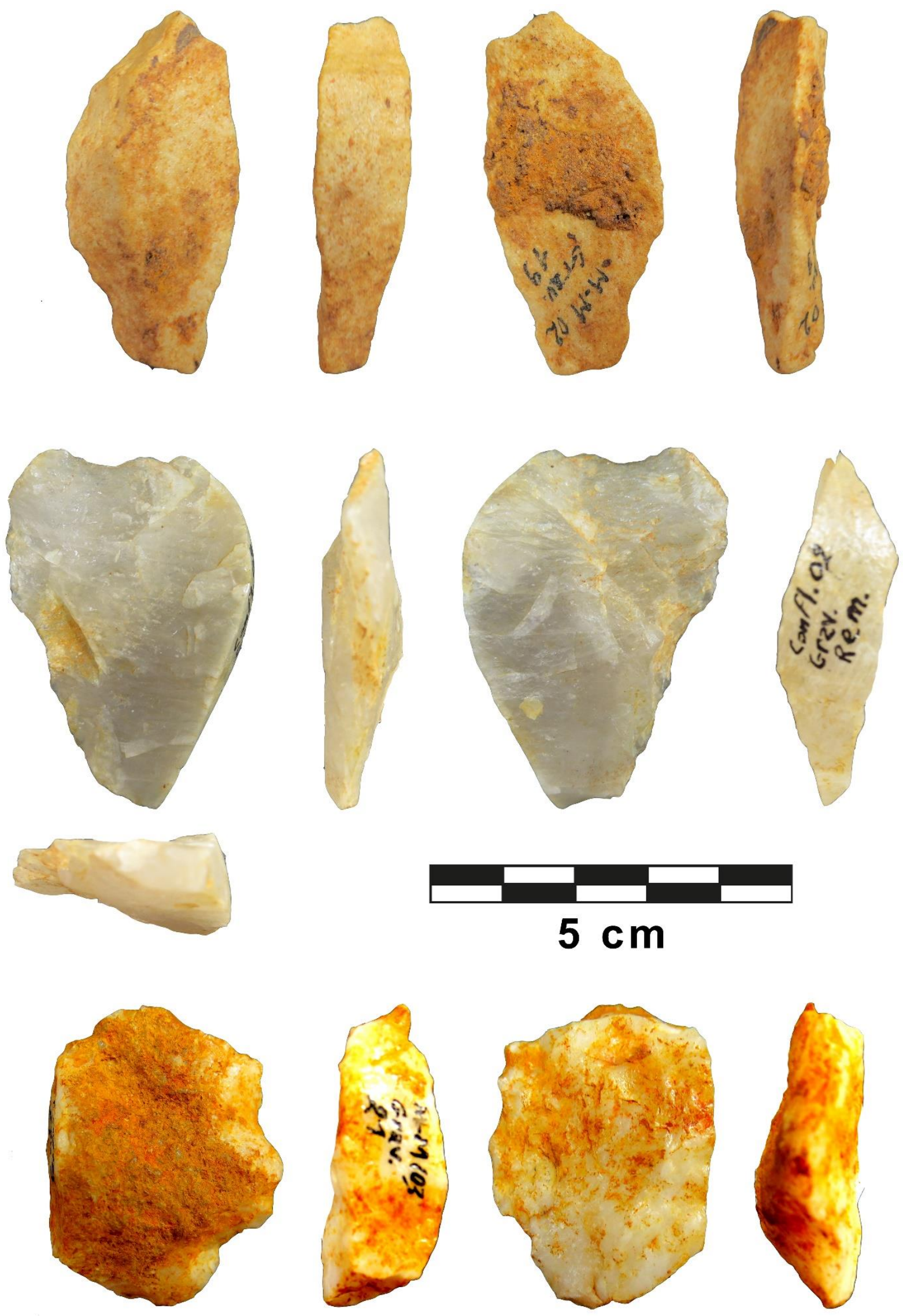

Figure 16. Example of flake morphology at Ounjougou. 


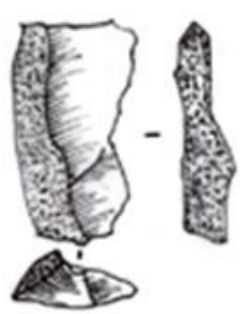

a

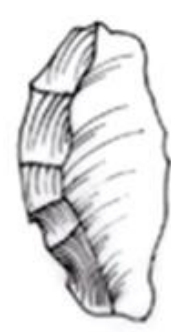

$\triangle$

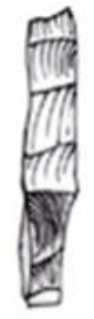

$\mathrm{b}$

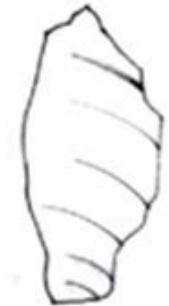

b

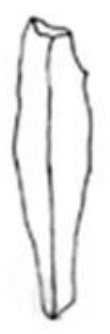

c

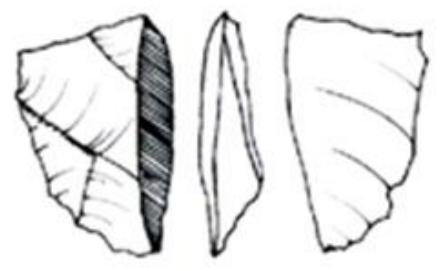

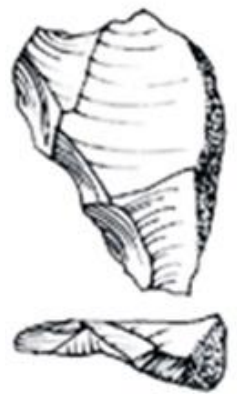

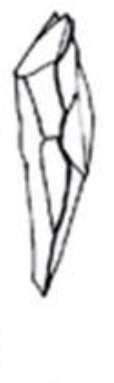

d
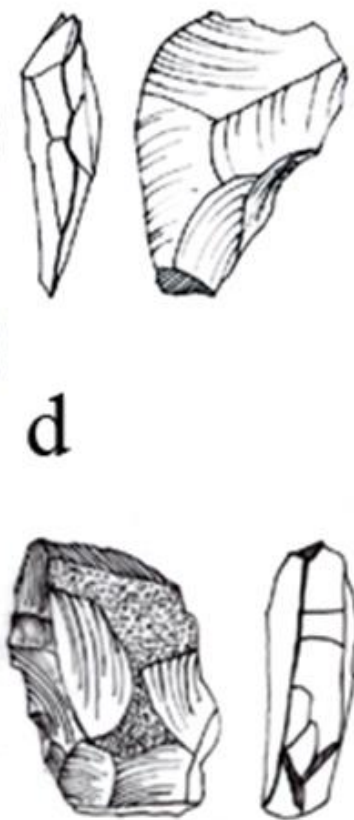

g
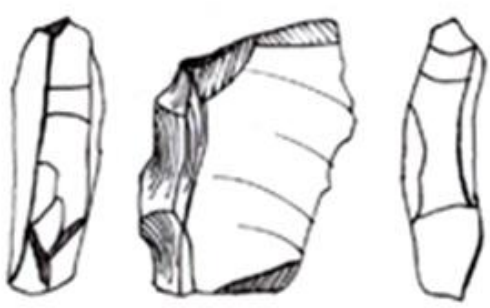
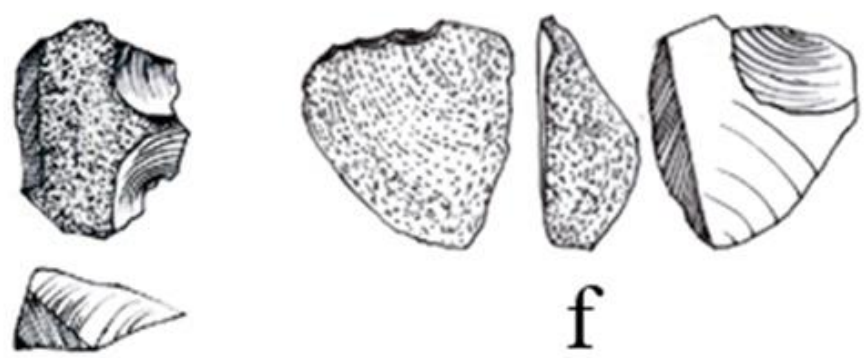

$\mathrm{f}$

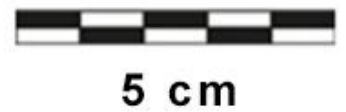

Figure 17. Tools on flakes.

The research of backed pieces (natural or shaped) is the most important component of the small duty tools.

The heavy-duty tools were shaped on different types of blanks but one can observe a selection of elongated pebbles. All are shaped on an extremity to obtain a transverse cutting edge associated to the pebble mass (Figure 18, a; b). A slab was shaped the same way on its extremity, and the side edge was trimmed to get a more effective handling (Figure 18, c).

A smaller pebble was shaped on its lateral edge, creating a denticulation (Figure 19, a). Two thick flakes were also retouched (Figure 19, b; c), and a thick block has been modified on one edge with steep removals, isolating a prominent thick cutting edge (Figure 19, d).

Compared with the total number of artifacts comprised in this assemblage, the tool kit is well represented, allowing the characterization of a wide mineral technical system.

\section{Discussion}

The Lower levels of Ounjougou complex delivered an important testimony of the Early Stone Age in Western Africa. Although a relative low number of artefacts, the diversity of the technical system opens a wide range of activities for the populations of this area. A systematic flake débitage on quartz and quartzite pebbles has been highlighted, with notch retouches, 
denticulated cutting edges and backed flakes. Associated with those small tools, the shaping of heavy-duty tools on quartzite and sandstone pebbles and slabs, this assemblage presents the classical criteria of Early Stone Age tool kit (Leakey 1971; de Lumley \& Beyene 2004). The shaping of spheroids and bolas also fits with well-known assemblages such as Ain Hanech in Algeria (Sahnouni \& de Heinzelin 1998; Sahnouni et al. 2002), Olduvai Beds I and II (Leakey 1971; Mora \& de la Torre 2005) and Isenya (Roche \& Texier 1991; Texier \& Roche 1995).
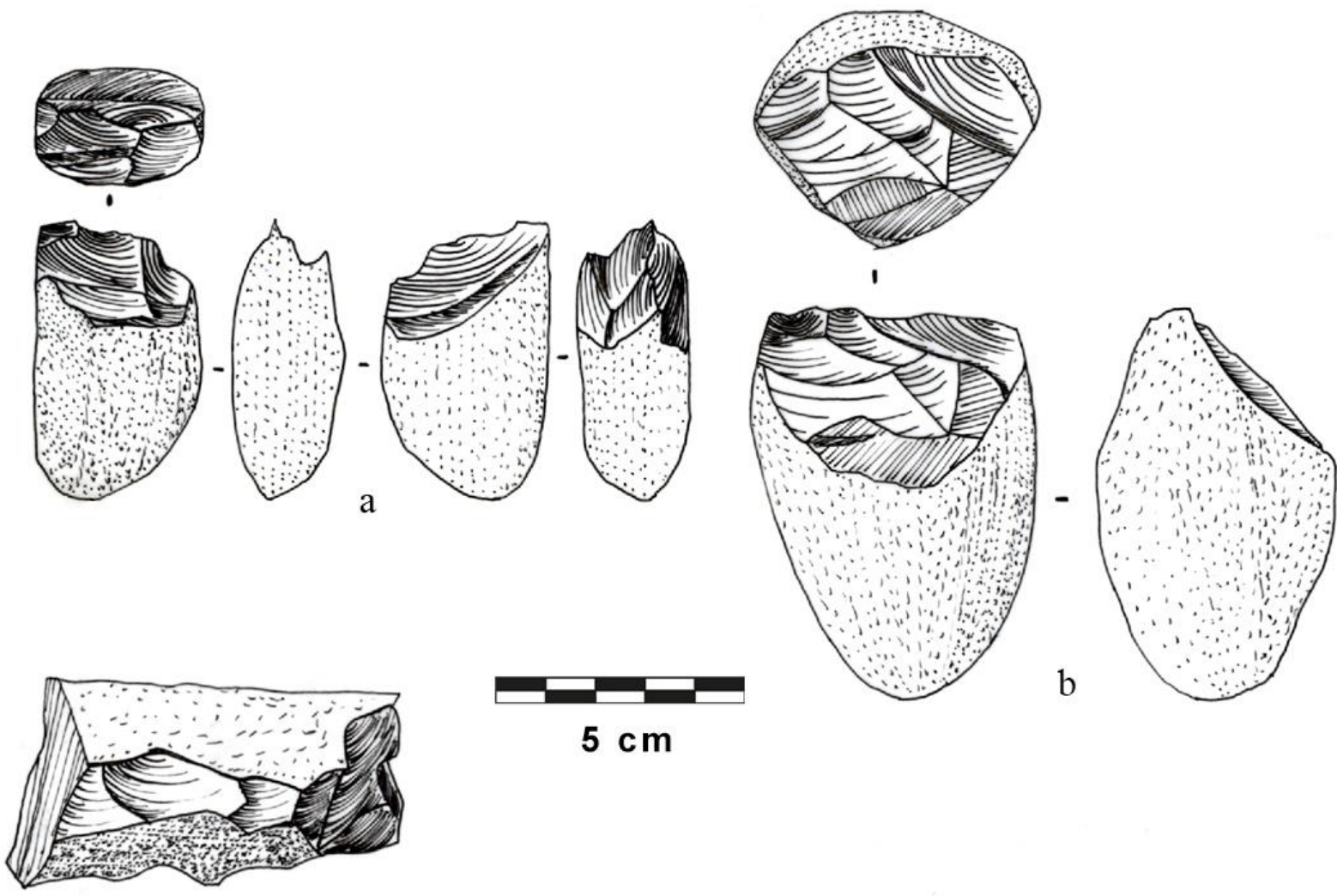

\section{$5 \mathrm{~cm}$}
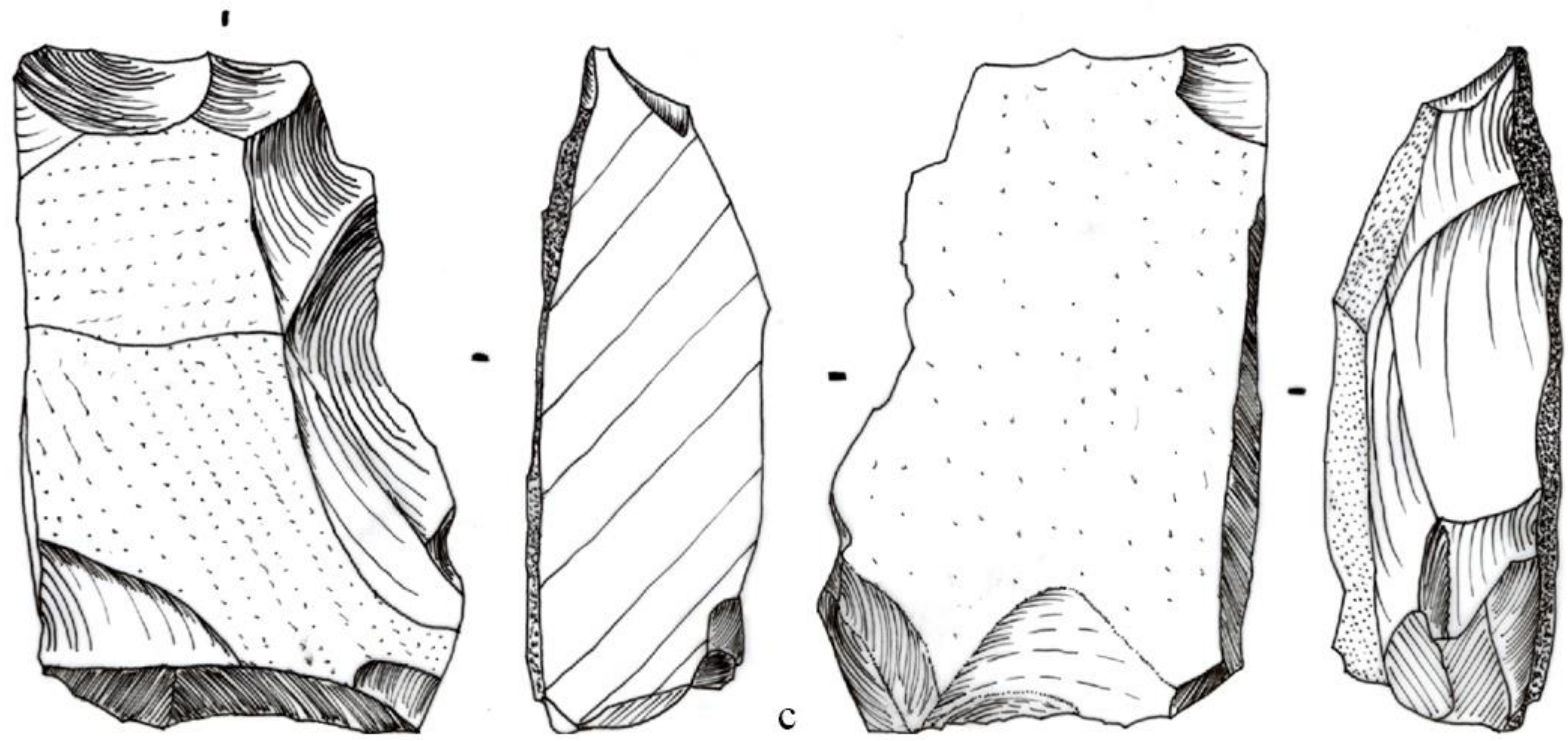

Figure 18. Tools on pebbles ( $\mathrm{a} ; \mathrm{b})$ and slab (c), transformative part shaped on an extremity.

Although we lack a clear chronological range for these levels, with only the 150ka BP terminus ante quem (Soriano et al. 2010: 6), the collection present all the attributes of an archaic industry. If discovered in Eastern Africa, it would be associated with no hesitation 
with the Oldowan or Developed Oldowan techno-complex (Leakey 1971; de Lumley \& Beyene 2004; Mora \& de la Torre 2005; Sahnouni 2005; Schick \& Toth 2006). If being completely affirmative is not relevant in this chrono-strtigraphic context, identifying the evidence of an early hominin settlement in Western Africa is already an important step, especially where the stratigraphical sequences are so cruelly lacking (McBrearty \& Brooks 2000; Robert et al. 2003). On the other hand, the hypothesis of a very old age for this industry is strengthened by the absence of Acheulean bifacial tools and cleavers although surface findings are well-known in the region (Aumassip \& Chaïd-Saoudi 2004).
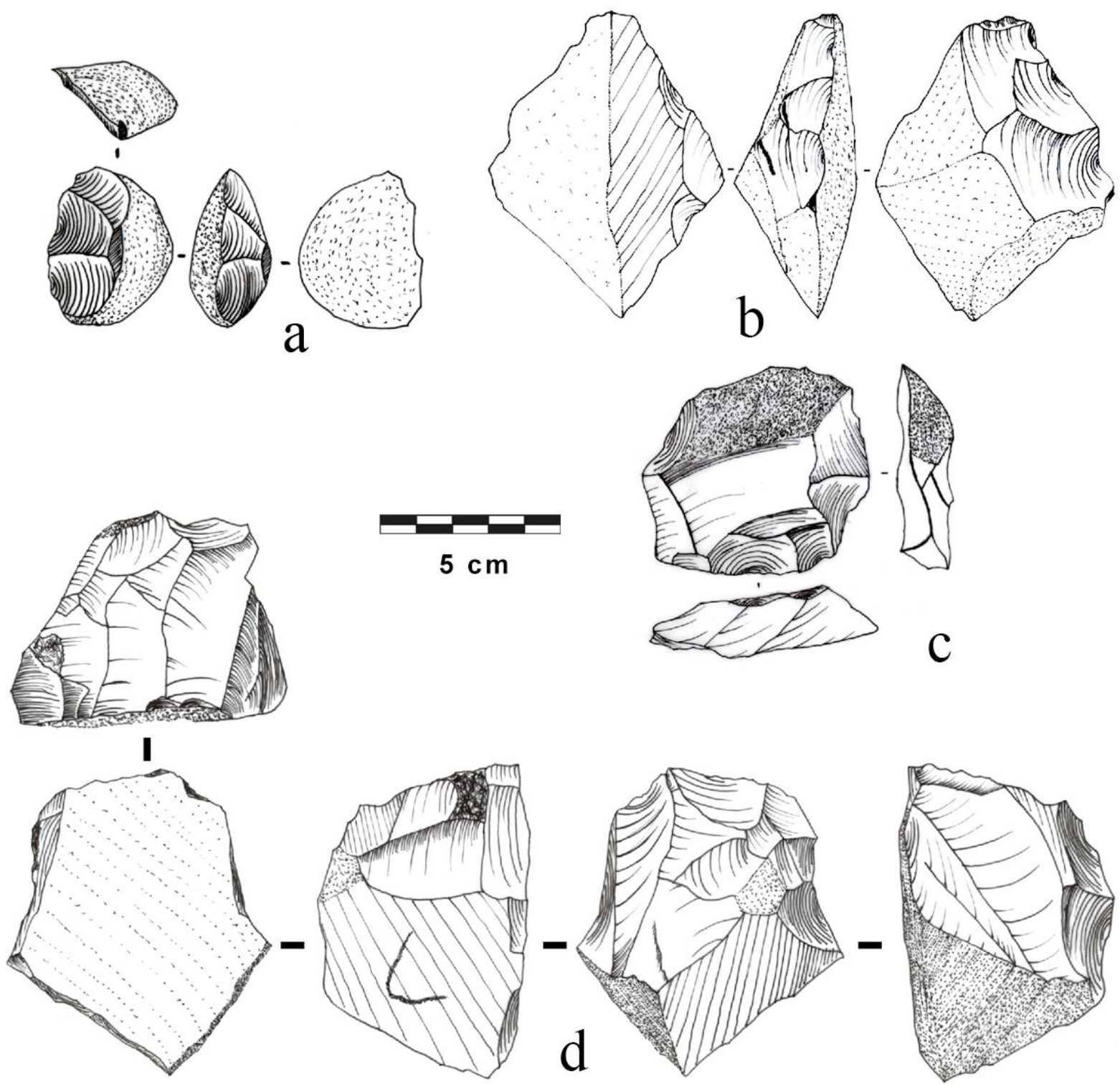

Figure 19. Other shaped tools. a. lateral edge modified pebbles; b. and c. thick retouched flakes; d. shaped block.

The originality of Ounjougou assemblage is clearly the presence of completely shaped spheroids and bolas. A very few part of them keep natural faces, like Ain Hanech or Olduvai Gorge spheroids (Leakey 1971; Mora \& de la Torre 2005; Sahnouni et al. 1997; 2002). On the other hand, this integral shaping is described in Isenya (Roche \& Texier 1991; Texier \& Roche 1995). Nevertheless, at Ounjougou polyhedrons and spheroids clearly belong to independent chaînes opératoires, with completely distinct objectives. This configuration does 
not match with the segments of the same chaîne opératoire to realize a single project described by P.J. Texier and H. Roche (1995).

Regarding the data recorded, it appears that the term polyhedron itself is reductive and does not make sense to the tools identified in this context. In fact, the so-called "polyhedrons" in this site refer to structured tools, completely shaped to create a transformative zone individualized by long adjacent removals, opposed to a maintaining zone that is also shaped. The structural analysis was useful to discriminate a core and two tool types from this category.

This identification does not mean that the term should be abandoned, but we think it should be exclusive to two situations that are not present in Ounjougou. First, to identify a technical step of spheroid confection as proposed for Isenya by P.J. Texier and H. Roche (1995), and second to name the natural sub-spheroid manuports described in Olduvai Gorge Beds I and II (Leakey 1971; Mora \& de la Torre 2005).

Another issue concerns spheroids functionality. Taking account of all the technical diversity identified within the assemblage, the hypothesis of a percussive objects not convincing. Firstly, because some polyhedrons do present more criteria that approach this functional potential (tool-type 1, Figure 9), and secondly because the work involved in shaping those spheroids and bolas, covering the entire surface of the artifact and intentionally orientated to get spheroid pieces, is showing a very precise strategy that implies the idea of a rotation of the techno-functional units all around the piece.

Any stigma may connect those tools with hunting activities, though this hypothesis used to be widely discussed (Isaac 1976; Leakey 1931; Leakey \& Leakey 1951; Willoughby 1987). Other authors considered those artefacts as being the result of a regular knapping process (Sahnouni et al. 1997; Schick \& Toth 1994) but in this case, all the cores and tools described does not show an important dimensional homogeneity, and it is not possible to consider the cores and tools as part of the same chaîne opératoire. Moreover, those artefacts are associated with a systematic quartz débitage process to produce flakes.

Based on those facts, we are inclined to propose the hypothesis of a grinding process, or vegetable pounding. This action would consist of crushing vegetable, grains, plants or skin by placing the tool directly on the material worked, and rotate it by a palm movement. Grinding activities are well known for the Neolithic (Dubreuil 2001) and more recent Paleolithic periods (Sánchez-Yustos et al. 2015; Willoughby 1985; 1987), but has never been proposed for earlier periods. However, the tool structure fits very well with a grinding process with first the use of a pointed spheroid to crush the vegetable, and then use the bola or faceted to smoothed spheroids to get powder or smooth a skin. Such operations and stigma have been previously defined (de Beaune 1989).

Nevertheless, those are preliminary hypotheses, based on the structural analysis and the study of the functional potentials. Although use-wear analyses should be performed to get evidences of our proposition (a use-wear approach will be tested in close future), it is important to notice that taking into account the whole assemblage, the application of a specific chaîne opératoire to produce those spheroids and bolas is relevant to get effective tools for a specific activity. Then, the most important feature of this study is to point out and demonstrate that those tools were made for a precise and exclusive activity.

\section{Conclusion}

This paper focused on the Early Stone Age assemblage of Ounjougou lower levels. Although we are not able to fix the dating of those levels, the geological situation combined with the technological analysis give evidences to propose an ancient age for this industry, and at least include it in the variability of the Oldowan techno-complex. As a matter of facts, the 
extreme rarity of long stratigraphic sequences in Western Africa makes this sequence exceptional.

The structural analysis of shaped tools, spheroids and bolas allowed bringing several hypotheses about the function and use of those artifacts, and a use-wear analysis should be performed in the future to confirm and complete our knowledge.

\section{Acknowledgements}

Field project on Stone Age periods at Ounjougou was funded by the French Ministry of Foreign Affairs through a grant to S. Soriano within the framework of the international research program "Human settlement and palaeoenvironment in West Africa", under the direction of Eric Huysecom (http://www.ounjougou.org/en/). Sylvain Soriano, Benoit Chevrier and Laurence Bourguignon provided useful critiques and corrections to this paper; Amir Beshkani allowed me to use his drawing (Figure 10) and provided accurate advises about the other drawings. The reviewers gave interesting comments and suggestions to improve the quality of this paper. I sincerely thank them.

\section{References}

Arambourg, C. 1950, Traces Possibles d'une Industrie Primitive dans un Niveau Villafranchien de L'Afrique du Nord. Bulletin de la Société Préhistorique Française, 47: 348- 350. (in French) ("Possible traces of a primitive industry in a Northern African Villafranchian level”). doi:10.3406/bspf.1950.2709

Archambault de Beaune, S. 1989, Exemple ethnographique de l'usage pluri-fonctionnel d'un galet de quartz. Bulletin de la Société Préhistorique Française, 86(2): 61-64. (in French) ("An ethnographic example of the multi-functional use of a quartz pebble") doi:10.3406/bspf.1989.9363

Aumassip, G., \& Chaïd-Saoudi, Y. 2004, Préhistoire du Sahara et de ses abords, 1. Au temps des chasseurs, le paléolithique. Maisonneuve \& Larose, Paris, 381 p. (in French) ("Prehistory of the Sahara and its surroundings, 1. At the time of hunters, the Palaeolithic")

Balout, L. 1955, Préhistoire de l'Afrique du Nord. Essai de Chronologie. Arts et Métiers Graphiques, Paris, 535 p. (in French) ("Prehistory of the Northern Africa. An essay on chronology")

Bayle Des Hermens, R. de 1975, Recherches préhistoriques en République centraficaine. Klincksieck, Paris, 343 p. (in French) ("Prehistoric researches in Central African Republic")

Clark, J.D. 1982, The Cambridge history of Africa, From the earliest times to C. 500 BC, Vol. 1, Cambridge University Press, Cambridge, 1173 p.

Dubreuil, L. 2001, Etudes fonctionnelles du materiel de broyage en préhistoire: Recherches méthodologiques. Bulletin du Centre de recherche français à Jérusalem, 9: 9-26. (in French) ("Functional studies of grinding material in Prehistory: Methodological researches") URL: http://bcrfj.revues.org/1682

Huysecom, E., Ozanne, S., Cissé, L., Doutrelepont, H., Gallay, A., Konaté, D., Mayor, A., Raeli, F., Robert, A., Sanogo, K., Soriano, S., Sow, O., \& Stokes, S. 2004, Du Paléolithique ancien à nos jours: La séquence archéologique et paléoenvironnementale 
du gisement d'Ounjougou (Pays Dogon, Mali). In: Actes du XXIe Congrès de l'Association Panafricaine de Préhistoire et disciplines assimilées (Sanogo, K., \& Togola, T. Eds.), Institut des Sciences Humaines, Bamako: p. 289-327. (in French) ("From the ancient Palaeolithic to the present-day: The archaeological and palaeoenvironmental sequence of the Ounjougou site (Pays Dogon, Mali)")

Isaac, G.L. 1976, Plio-Pleistocene artifact assemblages from East Rudolf, Kenya. In: Earliest Man and environments in the Lake Rudolf Basin. Stratigraphy, paleoecology and evolution (Coppens, Y., Howell, F.C., Isaac, G.L., \& Leakey, R.E.F. Eds.), University of Chicago Press, Chicago: p. 552-564.

Jones, P.R. 1994, Results of experimental work in relation to the stone industries of Olduvai Gorge. In: Olduvai Gorge, Vol. 5 Excavations in Beds III, IV and the Masek Beds, 1968-1971 (Leakey, M.D., \& Roe, D.A., Eds), Cambridge University Press, Cambridge: p. 254-298.

Leakey, L.S.B. 1931, The Stone Age cultures of Kenya Colony. Cambridge University Press, Cambridge, $287 \mathrm{p}$.

Leakey, M.D., \& Leakey, L.S.B. 1951, Excavations at the Njoro River Cave: Stone Age Cremated Burials in Kenya Colony. Oxford University Press, New York, 78 p.

Leakey, M.D. 1971, Olduvai Gorge, Vol. 3 Excavations in Beds I and II, 1960-1963. Cambridge University Press, Cambridge, 306 p.

Lespez, L., Rasse, M., Le Drezen, Y., Tribolo, C., Huysecom, E., \& Ballouche, A. 2008, L'évolution hydromorphologique de la vallée du Yamé (pays Dogon, Mali): signal climatique et hydrosystème continental en Afrique de l'Ouest entre 50 et 40 ka cal. BP. Géomorphologie: Relief, processus, environnement, 3: 170-185. (in French) ("The hydro-morphological evolution of the Yamé Valley (pays Dogon, Mali): Climatic signal and continental hydro-system in Western Africa between 50 and 40 ka cal. BP."). doi:10.4000/geomorphologie.7053

de Lumley, H., \& Beyene, Y. (Eds.) 2004, Les sites préhistoriques de la région de Fejej, SudOmo, Ethiopie, dans leur contexte stratigraphique et paléontologique. Editions Recherche sur les Civilisations, Paris, 635 p. (in French) ("The prehistoric sites of the Fejej region, South-Omo, Ethiopia, in their stratigraphic and palaeontological context)

McBrearty, S., \& Brooks, A. 2000, The revolution that wasn't: A new interpretation of the origin of modern human behavior. Journal of Human Evolution, 39: 453-563. doi:10.1006/jhev.2000.0435

Mora, R., \& de la Torre, I. 2005, Percussion tools in Olduvai Beds I and II (Tanzania): Implications for early human activities. Journal of Anthropological Archaeology, 24(2): 179-192. doi:10.1016/j.jaa.2004.12.001

Rasse, M., Soriano, S., Tribolo, C., Stokes, S., \& Huysecom, E. 2004, La séquence pléistocène supérieure d'Ounjougou (Pays dogon, Afrique de l'Ouest): Évolution géomorphologique, enregistrements sédimentaires et changements culturels. Quaternaire, 15(4): 329-341. (in French) ("The upper Pleistocene sequence of Ounjougou (Pays dogon, Western Africa): Geomorphological evolution, sedimentary records and cultural changes") doi:10.3406/quate.2004.1779

Rasse, M., Ballouche, A., Huysecom, E., Tribolo, C., Ozainne, S., Le Drezen, Y., Stokes, S., \& Neumann, K. 2006, Évolution géomorphologique, enregistrements sédimentaires et dynamiques paléoenvironnementales holocènes à Ounjougou (Plateau dogon, Mali, 
Afrique de l'Ouest). Quaternaire, 17: 61-74. (in French) (“Geomorphological evolution, sedimentary records and Holocene paleo-environmental dynamics at Ounjougou (Plateau dogon, Mali, Western Africa)") doi:10.4000/quaternaire.677

Robert, A., Soriano, S., Rasse, M., Stokes, S., \& Huysecom, E. 2003, First chrono-cultural reference framework for the West African Paleolithic: New data from Ounjougou, Dogon Country, Mali. Journal of African Archaeology, 1(2): 151-169. doi:10.3213/1612-1651-10007

Roche, H., \& Texier, P.J. 1991, La notion de complexité dans un ensemble lithique: application aux séries acheuléennes d'Isenya (Kenya). In: 25 ans d'études technologiques en préhistoire: Bilan et perspectives. Rencontres int. d'archéol. et d'hist., Vol. 11 (Antibes, 18-20 oct. 1990). Éditions APDCA, Juan-les-Pins: p. 99-108. (in French) ("The concept of complexity in a lithic assemblage: Application to Acheulean series of Isenya (Kenya)")

Sahnouni, M., (Ed.) 2005, Le Paléolithique en Afrique: l'Histoire la plus longue. Errance, Paris, 256 p. (in French) ("The Palaeolithic in Africa: The longest history)

Sahnouni, M., Schick, K., \& Toth, N. 1997, An Experimental Investigation into the Nature of Faceted Limestone "Spheroids" in the Early Palaeolithic. Journal of Archaeological Science, 24: 701-713. doi:10.1006/jasc.1996.0152

Sahnouni, M., \& de Heinzelin, J., 1998, The site of Ain Hanech revisited: New Investigations at this Lower Pleistocene site in Northern Algeria. Journal of Archaeological Science, 25: 1083-1101. doi:10.1006/jasc.1998.0278

Sahnouni, M., Hadjouis, D., Van der Made, J., Derradji, A., Canals, A., Medig, M., Belahrech, H., Harichane, Z., \& Rabhi, M. 2002, Further research at the Oldowan site of Ain Hanech, northeastern Algeria. Journal of Human Evolution, 43: 925-937. doi:10.1006/jhev.2002.0608

Sánchez-Yustos, P., Díez-Martín, F., Díaz, I.M., Duque, J., Fraile, C., \& Domínguez-Rodrigo, M. 2015, Production and use of percussive stone tools in the Early Stone Age: Experimental approach to the lithic record of Olduvai Gorge, Tanzania. Journal of Archaeological Science Reports, 2: 367-383. doi:10.1016/j.jasrep.2016.08.019

Schick, K., \& Toth, N. 1994, Early Stone Age technology in Africa: A review and case study into the nature and function of spheroids and subspheroids. In: Integrative Paths to the Past. Paleoanthropological Advances in Honor of F. Clark Howell (Corruchini, R.S., \& Ciochon, R.L., Eds.), Prentice Hall, New Jersey: p. 429-449.

Schick, K., \& Toth, N., (Eds.) 2006, The Oldowan: Case studies into the Earliest Stone Age. Stone Age Institute Press, Bloomington, Indiana, 338 p.

Soriano, S., Rasse, M., Tribolo, C., \& Huysecom, E. 2010, Ounjougou: A long Middle Stone Age sequence in the Dogon country (Mali), In: West African Archaeology. New developments, new perspectives (Allsworth-Jones, P., Ed.), BAR International Series Vol. S2164. Archaeopress, Oxford: p. 1-14.

Soriano, S., \& Huysecom, E. 2012, Lithic industry as an Indicator of Ceramic Diffusion in the Early Neolithic of West Africa: A Case Study at Ounjougou (Mali). Journal of African Archaeology, 10(1): 85-101. doi:10.3213/2191-5784-10212

Texier, P.J., \& Roche, H. 1995, Polyèdre, sub-sphéroïde, sphéroïde et bola: Des segments plus ou moins longs d'une même chaîne opératoire. Cahier Noir, 7: 31-40. (in French) 
("Polyhedron, sub-spheroid, spheroid and bola: More or less long segments of the same reduction sequence")

Tribolo, C., Rasse, M., Soriano, S., \& Huysecom, E. 2015, Defining a chronological framework for the Middle Stone Age in West Africa: OSL ages at Ounjougou (Mali). Quaternary Geochronology, 29: 80-96. doi:10.1016/j.quageo.2015.05.013

Toth, N. 1985, The Oldowan reassessed: A close look at early stones artifacts. Journal of Archaeological Science, 12(2): 101-120. doi:10.1016/0305-4403(85)90056-1

Willoughby, P.R. 1985, Spheroids and battered stones in the African Early and Middle Stone age. World Archaeology, 17(1): 44-60. doi:10.1080/00438243.1985.9979949

Willoughby, P.R. 1987, Spheroids and battered stones in the African Early and Middle Stone age. Cambridge Monographs in African Archaeology, 17. BAR International Series Vol. 321, British Archaeological Reports, Oxford: 253 p. 